\title{
Osmanlı Tekkelerinde Beslenme XVI. Yüzyılda İstanbul'daki Halveti Tekkeleri Örneği ${ }^{1}$
}

Ayşe Bölükbaşı

\section{Özet}

XVI. yüzyılda İstanbul'da mevcut Halveti tekkeleri beslenme ihtiyaçlarını karşıladıkları yer açısından kendi matbahı olan tekkeler, beslenme ihtiyacını mensup olduğu külliyenin imaretinden karşılayanlar ve beslenme ihtiyacını nereden karşıladığı bilinmeyen tekkeler olarak üç gruba ayrılıyordu. Tekkelerin sağladığı beslenme imkanlarından ise tekke personeli, şayet tekke külliye içinde bulunuyorsa külliyenin diğer birimlerindeki görevliler, tekkenin etrafında yaşayan fakir fukara, tekkede konaklayan misafirler, mübarek gün ve gecelerde tekkeye gelen giden herkes istifade edebiliyordu. Tekkelerin geniş toplumsal kesimlere hizmet vermesi birçok kişinin tekkelerle irtibata geçmesini sağlıyordu.

Vakfiyelerde beslenme için ayrılan tahsisat, yemek hazırlayan görevliler, matbahta kullanılan alet ve edevat gibi hususlarda ayrıntılı açıklamalar yapılmaktadır. Ancak tekke matbahlarının fiziki özellikleri konusunda kısıtlı bilgiler vardır. Tekke matbahları imaret gibi faaliyet gösteren devasa büyüklükte yapılar olabildiği gibi daha mütevazı boyutlarda da olabiliyordu. Matbahlar mekânsal açıdan incelendiğinde genellikle tekke matbahının selamlık ünitesi birimlerinin yakınına yerleştirildiği tespit edilmektedir. Vakıf belgelerinde matbah dışında taamhane, kilar, fırın gibi beslenme birimlerden de bahsedilmektedir. Bu yapılar da çoğunlukla tekke matbahının yanında konumlandırilıyordu.

Anahtar Kelimeler: Tekke, Halveti, tekke matbahı, imaret

\footnotetext{
${ }^{1}$ Bu makale Ayşe Bölükbaşı'ya ait (XVI. Yüzyılda İstanbul'daki Halveti Tekkeleri, İstanbul Teknik Üniversitesi, Fen Bilimleri Enstitüsü, Basılmamış Doktora Tezi, dan. Prof. Dr. Illknur Kolay, İstanbul 2015) künyeli tezin IV. ve V. bölümlerinin bazı kısımları esas alınarak hazırlanmıştır.

${ }^{2}$ Dr. Öğr. Üyesi, Bilecik Şeyh Edebali Üniversitesi, Güzel Sanatlar ve Tasarım Fakültesi, Endüstri Ürünleri Tasarımı Bölümü, ayse.bolukbasi@bilecik.edu.tr. (Makale Gönderim Tarihi: 22.03.2018; Makale Kabul Tarihi: 04.04.2018) (ORCID ID: 0000-0003-25370166).
}

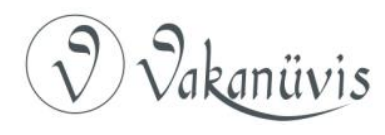




\title{
Nourishment in the Ottoman Dervish Lodges: The Example of Halwati Lodge in Istanbul in the $16^{\text {th }}$ Century
}

\begin{abstract}
In the sixteenth century of Istanbul, the Khalwati convents could be classified into three groups considering how they satisfy the need for food; the convents with its own kitchen, the convents that supply the food from the imaret of the complex, the convents about which we have no information where to meet the need for food. The convents were serving meals to the the convent staff, the household of the sheikh, the staff of other units in the complex -if the convent was constructed in a complex, the poor, the guests that spent the night in the convents and the guests on blessed days and nignts. Owing to serving food to a large segment of society, the convents got in touch with many people.

Although the fund for feeding people, the staff who prepares food and kitchen utensils etc. were registered in detail in vakf documents, it is possible to find limited information about architectural details of the convent kitchens. Convent kitchens could have been in modest dimensions as well as large scale structures operating like imaret. When the kitchens are examined from a spatial point of view, it is seen that the convent kitchen was placed near the units of the "selamlık" unit. In the vakf documents also, feeding units such as "taamhane", "kilar", "fırın" are mentioned. These structures were mostly located near the convent kitchen.
\end{abstract}

Keywords: Convent, Khalwati, convent kitchen, imaret

Osmanlı tasavvuf kültüründe tekke müntesiplerine, fakir fukaraya, "ayende ve revendeye" çeşitli ikramlarda bulunulması, mübarek gün ve gecelerin helva ve aşure gibi yiyeceklerin ikramıyla şenlendirilmesi çok önemli bir yere sahipti. Tekkede pişirilen çorbanın ve kurulan sofranın hususi bir ehemmiyeti vardı ${ }^{3}$. Osmanlı Devleti'nin kuruluş yıllarında zaviyeli camiler ${ }^{4}$, imaretler ve tekke matbahları toplumun farklı kesimlerinin beslenme ihtiyacını karşılıyordu. Zamanla mimari yapılar gelişmiş, mütevazı ve çok fonksiyonlu zaviyeli camilerin yerini

\footnotetext{
${ }^{3}$ Nev'izade Atâî, Hadaiku'l Hakaik fi Tekmileti'l-Şakaik, nşr. A. Özcan, İstanbul 1989, s. 81, 203-204; Güldane Gündüzöz, "Osmanlı Tekke Mutfak Kültürü ve Mecmuâ-i Fevâid", Cumhuriyet Ilahiyat Dergisi, sayı: 20-2 (Aralık 2016), s. 175-205.

${ }^{4}$ Semavi Eyice, "ilk Osmanlı Devrinin Dini İctimai Bir Müessesesi: Zaviyeler ve Zaviyeli Camiler" Istanbul Üniversitesi Iktisat Fakültesi Mecmuası (23), İstanbul 1963, s. 1-80.
}

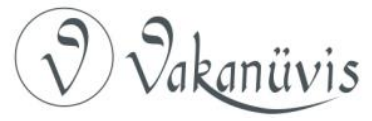


büyük camiler almıştır. Bu değişime paralel olarak imaretler ve tekke matbahları da gelişme kaydetmiştir. Özellikle imaretler kuruluş yıllarındaki küçük örneklerin yerine çok sayıda insanın beslendiği, zengin imkanlara sahip devasa kurumlara dönüşmüşlerdi ${ }^{5}$.

Tekke matbahları ise tekkede yaşayan şeyh ve dervişanın, bazen tekkenin mensup olduğu külliyenin diğer birimlerindeki görevlilerin, misafirlerin ve tekkenin yakınında yaşayan fakir fukaranın yemek ihtiyacını karşılamaktaydı. Tekke matbahları özellikle mübarek gün ve gecelerde imaretlere benzer bir fonksiyon icra ediyordu' 6 . Nitekim Evliya Çelebi tekke matbahlarını bir imaret türü olarak değerlendiriyordu?

XVI. yüzyılda payitaht İstanbul'un en yaygın tarikatlarından biri olan Halvetilik güçlü bir toplumsal etkiye sahipti ${ }^{8}$. Bu dönemde İstanbul'da faaliyet gösteren Halveti tekkelerinin sayısı kırk beşti. Bunların önemli bir kısmı yönetici sınıfa mensup kişiler tarafından inşa ettirilmişti.

\footnotetext{
${ }^{5}$ Amy Singer, "Imarets" The Ottoman World, ed. C. Woodhead, London 2012, s. 72-85; Ayşe Budak, "İmaret Kavramı Üzerinden Erken Osmanlı Ters T Planlı Zaviyeleri ile Aşhanelerin İlişkisi: Osmanlı Aşhanelerinin Kökenine Dair Düşünceler" METU JFA 2016/1, (33:1) 21-36.

${ }^{6}$ Baha Tanman, "Kitchens of Ottoman Tekkes as Reflections of Imarets in Sufi Architecture", Feeding People Feeding Power, Imarets in the Ottoman Empire, ed. N.Ergin, C.K.Neumann, A.Singer, İstanbul 2007, s. 211-239. Tekke birimleri düşünüldüğünde matbahın zikir, tevhid gibi ritüellerin gerçekleştirildiği tevhidhane (semahane, meydan) yapısı ile türbe biriminden sonra en önemli kısım olduğu bilinmektedir. Mevlevi ve Bektaşi tekkelerinde matbah aynı zamanda tarikata yeni intisap eden dervişlerin yetiştirilmesinde ve tarikata kabulünde önemli bir yere sahiptir (Gökben Azsöz, "Mevlevihanelerde Matbah-ı Şerif" Toros Üniv. iiBF. Sosyal Bilimler Dergisi, Yıl:3, Sayı:5, Temmuz 2016, 31-43. Konuyla ilgili ayrıca bakınız: Güldane Gündüzöz, Bektaşi Kültüründe Yemek Motifi, Ondokuz Mayıs Üniv. Sosyal Bilimler Enstitüsü, Yayınlanmamış Yüksek Lisans Tezi, Samsun 2012).

${ }^{7}$ Amy Singer, "Evliya Çelebi on Imarets" Mamluks and Ottomans, Studies in Honour of Michael Winter, ed. by David J. Wasserstein and Ami Ayalon, London and New York 2006, s. 123-132.

8 Halvetiliğin payitahta girişi ve XVI. yüzyılda İstanbul'daki durumu için bakınız: Mahmud Cemaleddin Hulvi, Lemazat-ı Hulviyye ez Lemazat-ı Ulviyye (M. S. Tayşi, Haz.). İstanbul 1993; Tahsin Yazıcı, "Fetihten Sonra İstanbul'da İlk Halvetî Şeyhleri: Çelebi Muhammed Cemaleddin, Sünbül Sinan ve Merkez Efendi", İstanbul Fetih Cemiyeti, 1956, 2, s. 89-113; Reşat Öngören, Osmanlılarda Tasavvuf, Anadolu'da Sufiler Devlet ve Ulema (16. Yüzyıl), İstanbul 2000, s. 27-110; Zeynep Yürekli, "The Sufi Convent of Sokullu Mehmed Pasha in Istanbul", Muqarnas, 20, 2003, s. 159-185; Bölükbaşı, agt.
}

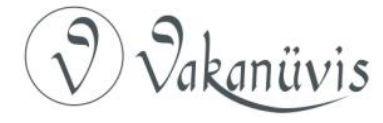


Bazıları devasa külliyeler içinde yer almaktaydı ve geniş imkanlara sahipti. Beslenme ihtiyaçlarını külliye imaretinden karşılıyorlardı. Pekçok tekkenin ise kendi matbahı vardı. Bu nedenle beslenme meselesine dair tekke vakfiyelerine kayda değer bilgiler yansımıştır. Elimizde kırk beş tekkeden sadece yirmi altısının vakıf belgesi mevcuttur. Vakıf belgesi olarak zikredilen kaynakların önemli bir kısmı tekkelerin vakfiyeleridir. Bir kısmına ait veriler ise döneme ait iki adet vakıf tahrir defterinden sağlanmaktadır. Bu çalışmada söz konusu veriler esas alınarak tekkelerdeki beslenme meselesi üzerinde durulacaktır?.

\section{1-) Beslenme İhtiyacını Karşılama Türlerine Göre Tekkeler}

Tekkeler beslenme intiyaçlarını karşılama biçimlerine göre kendi matbahlarından karşılayanlar, tekkenin mensup olduğu külliyenin imaretinden karşılayanlar ve beslenme ihtiyacını nasıl karşıladığı bilinmeyen tekkeler olarak üç ana grup altında toplanabilir. Incelememiz kapsamına giren tekkelerden on yedi tanesi kendi matbahına sahipti. Bunlar cami-tekke, mescit-tekke veyahut sadece tekke olan mütevazı yapılardı. Tekkelerden üç tanesi ise içinde bulundukları külliyelerin imaretinden yararlanmaktaydı. Bunlar çoğunlukla cami-tekke işlevindeki yapılardan oluşmaktaydı. Üçüncü grubu oluşturan diğer tekkeler ise ne matbaha sahipti, ne de dahil oldukları külliyelerde imaret bulunmaktaydı. Bunların beslenme ihtiyaçlarını nasıl karşıladıkları tam olarak tespit edilememiştir.

\section{Kendi Matbahı Olan Tekkeler}

XVI. yüzyılda İstanbul'da faaliyet gösteren kırk beş adet Halveti tekkesinden on yedi tanesinin kendine ait matbahı vardı: Balat, Küçük Ayasofya, Merkez Efendi, Mimar Acem Ali, Ramazan Efendi, Eyüp Şah Sultan, Yahya Kethüda, Soğukkuyu, Mehmed Ağa cami-tekkeleri; Alaeddin Efendi, Süleyman Ekmeleddin, Koruk, Hacı Kadın ve Koğacı Dede mescit-tekkeleri; Sokullu Mehmed Paşa, Doğancı Ahmed Paşa ve Sinan Erdebili tekkeleri matbaha sahip olan yapılardır ${ }^{10}$. Vakıf belgelerinde tekke matbahından her zaman doğrudan söz edilmemektedir. Ancak söz konusu belgelerde genellikle şeyh ve

\footnotetext{
${ }^{9}$ Ayrıntılı bilgi için bakınız: Bölükbaşı, agt.

${ }^{10}$ Tekkelere ait vakıf belgelerinin tamamı kaynakçada liste halinde verilmiştir.
}

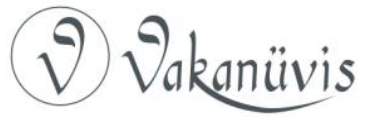


dervişlerin yemek ihtiyacı için ne kadar tahsisat ayrılacağından, günde kaç defa yemek verileceğinden, yemek için hangi malzemeden, ne kadar kullanılacağından ve mutfak eşyalarından bahsedilir; nadiren ise yemeği pişirecek tabbahın ne kadar ücret alacağına değinilirdi. Bu hususların herhangi birinin belgelerde zikredilmesi, tekkenin içinde bir matbah olduğuna işaret etmektedir.

Tekkelerinin bazılarının matbahı bir hayli büyüktü. Mesela Küçük Ayasofya Tekkesi bunlardan biriydi. Kiliseden cami-tekkeye dönüştürüldüğü ilk andan itibaren büyük bir matbaha sahipti. Çalışanların sayısı ve çeşitliliği göz önünde bulundurulduğunda, matbah aşhane niteliğinde bir imaret gibi görünmektedir. Vakfiyede yemek işiyle ilgilenen şeyh ${ }^{11}$, aşçı, ekmekçi, nakib, kilarcı, vekil-i harç, hizmetçi gibi çok sayıda görevliden bahsedilmektedir. Yine yemeğin zaviyede pişirilip, öncelikle zaviyenin derviş ve müridlerine dağıtılacağı vurgulanmaktadır $^{12}$. XVI. yüzyıl başlarına ait olan vakfiyede ne matbah, ne de imaret ifadesi geçmektedir. Ancak bu yapının zaviyenin bir birimi gibi anlatılması, büyükçe bir tekke matbahı olduğunu göstermektedir. Başlangıçta sadece tekke sakinlerinin yemek ihtiyacını karşılamak üzere inşa edilmiş olan matbah, Küçük Ayasofya Külliyesi'ne mektep gibi yeni birimlerin eklenmesinin ardından aşhane niteliğinde bir imarete dönüşmüş olmalıdır. Nitekim XVI. ve XVII. yüzyıla ait muhasebe defterlerinde artık zaviye içindeki bir birimden değil de aşhane niteliğinde bir "imaret" yapısından bahsedilmektedir ${ }^{13}$.

Tekkelerin çoğunun matbahı ise daha mütevazı boyutlardaydı. Mesela Doğancı Ahmed Paşa'nın tesis ettiği altı hücreli tekkenin bir hücresi matbah olarak ayrılmışı ${ }^{14}$. Tekkelerden bazılarında ise başlangıçta matbah yokken, inşasından bir süre sonra matbah eklenmişti. Alâeddin Efendi Tekkesi'ne ait eldeki ilk vakıf belgelerinde matbahtan ve buna bağlı olarak yemek masrafından

\footnotetext{
${ }^{11}$ İmarette yemek işinin başında olan kişi birçok vakfiyede şeyh diye anılmaktadır. Hatta bazen tekke şeyhini, imaret şeyhinden ayırt etmek için tekke şeyhi "seccade şeyhi" şeklinde zikredilmektedir (Piri Mehmet Paşa'nın Vakfiyeleri, VGMA. D, nr. 747, s. 178-181; s. 466-475; s. 481-501; Vakfiyelerin Türkçeleri; VGMA. D, nr. 1991, s. 165276).

12 Hüseyin Ağa Vakfiyesi, TSMA.D, nr. 6900, nr. 6977.

${ }^{13}$ TSMA. D, nr. 3607/3; nr. 3665/4.

${ }^{14}$ Doğancı Ahmed Paşa Vakfiyesi, VGMA.D, nr. 503, s. 327-336.
}

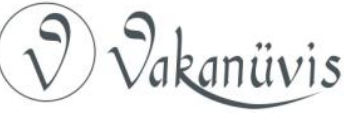


bahsedilmemektedir. Ancak daha sonra tekke vakfına ek olarak ilyas $b$. Abdullah ve Hafsa b. Abdulah tarafından tesis edilen Hicri 920 (15141515) tarihli vakıfla tekkeye bir kazan ve bir sini vakfedilmiştir. Ayrıca tarihsiz başka bir vakıf belgesinde ise tekkeye yedi kazan, beş sacayak, üç sini, on iki sahan, bir tepsi bağışlandığını aktarılmaktadır ${ }^{15}$. Çarşamba'daki Koğacı Dede Mescit-Tekkesi'nde de benzeri bir durum sözkonusudur. Koğacı Dede adıyla meşhur olan Şeyh Sevindik Dede'nin kurduğu vakıfta matbahtan bahsedilmezken, daha sonra tekke için yeni bir vakıf kuran İbrahim b. Abdullah'ür-Râcil'in tekkeye bir miktar paranın yanında yirmi sini ve yirmi sahan vakfeylediği bilinmektedir ${ }^{16}$.

Matbahı olan tekkelerden bir kısmına ait vakıf belgelerinde yemek için günlük ne kadar malzeme kullanılacağı anlatılırken, bazılarında tahsisat para olarak zikredilmiş, bir kısmında ise daha muğlak ifadeler kullanılmıştı. Günlük yemek tahsisatı en fazla 25 akçeye kadar çıkmaktaydı. Soğukkuyu Cami-Tekkesi, Merkez Efendi Tekkesi ve Eyüp Şah Sultan Tekkesi 25'er akçe ile matbahı en yüksek tahsisata sahip tekkelerdi ${ }^{17}$. Söz konusu rakam genellikle en yüksek tahsisata sahip olan imam ve şeyh gibi görevlilerin yevmiyesinden daha fazlaydı.

Küçük Ayasofya, Doğancı Ahmed Paşa ve Mehmed Ağa tekkelerine ait vakıf belgelerinde ise tahsisat nakdi olarak değil ayni olarak zikredilmiştir. Mesela Küçük Ayasofya Tekkesi'nde matbaha günlük bir

\footnotetext{
${ }^{15}$ Barkan ve Ayverdi, age, s. 313-314. Alâaddin Efendi Tekkesi şeyhi ve dervişleri tekke matbahının olmadığı ilk dönemde yemek ihtiyaçlarını, tekke külliyesi dışındaki başka bir imaretten ya da başka bir tekkenin matbahından karşılıyor olmalıdırlar. Burası oldukça yakında bulunan ve kendine ait matbahı olan Süleyman Ekmeleddin Tekkesi olabilir. Bu iki tekke arasındaki yakın ilişki başka hususlarda da mevcuttu. Süleyman Ekmeleddin Tekkesi'ne ait bir vakıf belgesinde, hilafetin mevcut şeyhin halifelerinden ve ehibbâsından en salihine, eğer uygun biri yoksa Alaüddin Efendi'nin halifelerinden birine kalması şart koşulmuştu. Neticede bu iki tekke de Halveti tekkesiydi. Aralarında yakın bir münasebet olması doğaldı (Barkan ve Ayverdi, age, s. 310; Canatar, age, s. 489).

${ }^{16}$ Barkan ve Ayverdi, age, s. 296.

${ }^{17}$ VGMA.D, nr. 503, s. 327-336; nr. 570, s. 29-33; nr. 571, s. 1-2; nr. 572, s. 27-63; nr. 633, s.158-169; nr. 747, s. 466-475; s. 481-501; nr. 1592, s. 1-40; nr. 1993, s. 11-17; nr. 2108, s. 63; TSMA.D, nr. 6900, 6977; AE. Sultan Bayezıd.II, 1/48; 1/49; Barkan ve Ayverdi, age, s. 310, 383; Canatar, age, s. 489; Mimar Acem Ali Tekkesi'nde ise aylık tahsisat başlangıçta 35 akçe iken, daha sonra 50 akçeye çıkarılmıştır (Kunter, agm, s. 438-443).
}

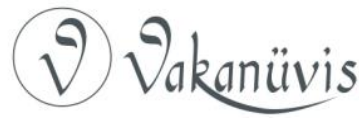


kile buğday ve sekiz okka koyun eti tahsis edilmişti. Buğdayın bir kısmı ekmek, bir kısmı da çorba pişirilmesi için kullanılacaktı. Hergün seksen ekmek pişirilecekti. Günde bir sefer yemek verilmesi şart koşulmuştu. Masraflardan para artarsa öğün sayısı ikiye çıkartılacaktı. Doğancı Ahmed Paşa Tekkesi'nde ise günde bir öğün yemek verilecekti. Pişirilecek çorba için ayda üç İstanbul kilesi buğday, bir okka zeytin yağı, yüz elli akçelik et, yeteri kadar nohut ve soğan temin edilecekti. Çorba pişirilirken kullanılmak üzere odun da alınacaktı. Verilen bilgilerden de anlaşılacağı üzere Küçük Ayasofya Tekkesi için ayrılan tahsisat, Doğancı Ahmed Paşa Tekkesi'nin tahsisatına göre oldukça yüksekti ${ }^{18}$.

Habeşi Mehmed Ağa Tekke'sinde de matbah için ayrılan tahsisat ayni olarak belirlenmişti. Vakfiyede zaviye sakinleri için ayda iki kile pirinç verilmesi, bunun Ramazan ayında bir buçuk kile arttırılması; bir kile mercimek veya buğday; yıllık otuz okka bal ve otuz yedi okka zeytin yağı, dört yüz seksen akçelik et; yıllık elli çeki odun, iki kile tuz ve iki kile nohut temin edilmesi şart koşulmuştu. Aşure vaktinde ise beş yüz akçelik aşure pişirilmesi; Berat ve Kadir gecesi gibi bazı özel günlerde iki yüz akçelik helva yapılması da ayrıca kayda geçirilmişti. Yapılan yemeklerin tekkedeki dervişlere, muallimhanede okuyan sıbyana, muallimlere ve halifelerine ve hazır olan fukaraya yedirilmesi istenmişti ${ }^{19}$. Verilen bu bilgiler akla tekke matbahının sadece dervişlerin değil, mübarek gün ve gecelerde külliyenin başka birimlerinin de yemek intiyacını karşılıyor olabileceği ihtimalini getirmektedir.

Sinan Erdebili Tekkesi'ne ait vakfiyede ise günlük yemek masrafı için ne kadar para ayrılacağı belirtilmezken, yemek için ne çeşit ve ne kadar malzeme alınacağı da açıklanmamıştır. Hicri 946/Miladi 1539 tarihli vakfiyede, vakfın gelirlerinden tamirat ve kira bedeli gibi zaruri harcamalar yapıldıktan sonra, kalan paradan mütevelliye ve zaviye şeyhine günlük üçer akçe verilmesi; artan paradan da tekkede sakin dervişanın yemek masraflarının karşılanması şart koşulmuştu ${ }^{20}$.

\footnotetext{
${ }^{18}$ TSMA.D, nr. 6900, nr. 6977; VGMA.D, nr. 503, s. 327-336.

${ }^{19}$ Habeşi Mehmed Ağa Vakfiyesi, TSMK, Emanet Hazinesi, nr. 3028, vr.89b-90a.

${ }^{20}$ Sinan Erdebili Vakfiyesi, VGMA. D, nr. 571, s. 1-2.
}

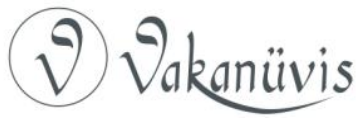




\section{Mensup Oldukları Külliyenin İmaretinden Faydalanan Tekkeler}

XVI. yüzyılda İstanbul'da faaliyet gösteren kırk beş adet Halveti tekkesinden üç tanesi ise beslenme ihtiyacını bağlı bulundukları külliyenin imaretinden karşlıyordu. Bunlar Atik Valide Tekkesi, Atik Ali Paşa Cami-Tekkesi ve Koca Mustafa Paşa Cami-Tekkesi'ydi. Bunlardan ikisi -Atik Valide ve Atik Ali Paşa tekkeleri- sadece yemek pişirilen, aşhane niteliğinde küçük yapılar değildi. Mesela Atik Ali Paşa imareti yemek pişirme için ayrılmış birimlerin yanında mahzeni, ahırı, kenifi ve odunluğu olan, aydınlatma için gerekli tahsisatların yapılmış olduğu oldukça büyük bir binaydı ${ }^{21}$. Bu tekkelerin bânileri zengin, nüfuzlu ve toplumsal statüsü yüksek kişilerdi. İkisi sadrazam, biri ise valide sultandı. Bu durum yaptırdıkları külliyenin sahip olduğu imkanları da bir hayli arttırmıştı ${ }^{22}$.

Atik Valide Külliyesi İstanbul'un en büyük külliyelerinden biri olarak pek çok binaya sahipti. Külliye imareti bu yapıların birçoğunun ihtiyaçlarını karşılıyordu. Vakfiyede külliyenin bütün birimlerindeki sakinlerin tahsisatı ayrıntılı bir şekilde anlatılmıştı. Dolayısıyla tekkede sakin şeyh ve dervişanın da tahsisatı vakfiyede kayıtıydı ${ }^{23}$. Ancak Koca Mustafa Paşa ve Atik Ali Paşa tekkelerinde tekke şeyhi ve dervişanın yemek tahsisatı tasrih edilmemiş; genel hatlarıyla bütün külliye için ne kadar yiyecek temin edilip, yemek yapılacağı anlatılmıştı ${ }^{24}$.

Atik Valide İmareti vakfiyesinde medrese, darülkurra ve darülhadisteki talebelerin her birine, çalışanlardan ferraş ve bevvaba günde iki öğün yemek verilmesi şart koşulmuştu. Vakfiyede tekke dervişanı içinse günde iki defa, on sekiz adet tam yemek verilmesi kaydedilmişti. ilk bakışta yemek sayısının derviş sayısına göre belirlenmiş olduğu düşünülebilir. Ancak Atik Valide Tekkesi'nde otuz iki dervişin ikamet ettiği vakıf belgelerinde kayıtlıdır. Nitekim derviş hücre

\footnotetext{
${ }^{21}$ Atik Ali Paşa Vakfiyesi, Süleymaniye, Esad Efendi, nr. 3673, vr. 18b-23a.

${ }^{22}$ XVI. yüzyılda İstanbul'da faaliyet gösteren Halveti tekkelerinin bânileri konusunda geniş bilgi için bakınız: Ayşe Bölükbaşı, "Halveti Tekkelerinin İnşasında Devlet Idarecilerinin Rolü" History Studies, Şerafettin Turan'a Armağan, Nisan 2014, cilt: 6, sayı: 3, s. 71-87.

23 Nurbanu Sultan Vakfiyesi, VGMA. D, nr. 2113, s. 281-309; Vakfiyenin Türkçesi, VGMA. D, nr. 1766, s. 136-170.

${ }^{24}$ Atik Ali Paşa Vakfiyesi, Süleymaniye, Esad Efendi, nr. 3673, vr. 18b-23a; Barkan ve Ayverdi, age, s. 369.
}

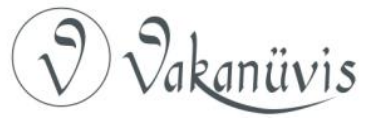


sayısı da bunu doğrulamaktadır. Günlük yemek konusundaki bu yetersizliğe Mevlid kandili gibi mübarek gün ve gecelerde rastlanmaz. Mevlid-i şerifin okunmasından önce bütün görevlilere verilmek üzere hazırlanacak on beş sofradan ikişer tanesinin medrese ve tekke sakinlerine ayrılması vakfiyede şart koşulmuştu ${ }^{25}$.

Bağlı bulunduğu imaretten yemek temin eden bu tekkelerin, kendilerine ait özel bir matbahı olmadığı anlaşılmaktadır. Tekkenin içinde bulunduğu külliyede imaret varsa, ayrı bir tekke matbahına ihtiyaç duyulmaması doğaldır.

\section{Beslenme İhtiyacını Nereden Karşıladığı Bilinmeyen Tekkeler}

XVI. yüzyılda İstanbul'da faaliyet gösteren Halveti tekkelerinden bazılarının ise kendi matbahı olmadığı gibi, içinde yer aldıkları külliyelerin de bir imareti yoktu. Elimizde vakıf belgesi olan yirmi altı tekkenin, altı tanesinin beslenme ihtiyacının nereden karşılandığına dair veri mevcut değildir. Üçüncü grubu oluşturan bu tekkelerden Dragoman Yunus Bey, İmrahor ilyas Bey ve Keşfi Cafer Efendi adlarıyla bilinen mütevazi tekkelere ait vakıf belgelerinde matbahtan, burada görevli bir tabbahtan ya da yemek için ayrılan tahsisattan bahsedilmemektedir ${ }^{26}$. Bu tekkelerin yemek ihtiyaçlarını yakın mesafedeki herhangi bir imaretten karşılamış olmaları muhtemeldir. Diğer üç tekkenin ise (Piyale Paşa ${ }^{27}$, Davutpaşa Şah Sultan, Şemsi Paşa) mevcudiyeti vakfiyelerinden ziyade diğer kaynaklardaki verilerden çıkarılmaktadır. Dolayısıyla beslenme meselesi de tamamen meçhuldür ${ }^{28}$. Özetle XVI. yüzyılda İstanbul'da faaliyet gösteren kırk beş Halveti tekkesinden, altı tanesine ait vakıf belgelerinde konuyla ilgili bilgi verilmemiştir. On dokuz adet tekkenin ise vakfiyesi mevcut

\footnotetext{
${ }^{25}$ Nurbanu Sultan Vakfiyesi, VGMA. D, nr. 2113, s. 281-309; Vakfiyenin Türkçesi, VGMA. D, nr. 1766, s. 136-170.

${ }^{26}$ Imarahor Illyas Bey Vakfiyesi, VGMA.D, nr. 747, s. 331-334; Barkan ve Ayverdi, age, s. 417-418; Canatar, age, s. 681-682.

27 Evliya Çelebi, Piyale Paşa Tekkesi civarında yemek ikramına dair bazı bilgiler vermektedir. Ancak bu bilgiler diğer kaynaklar tarafından teyit edilememektedir (Evliya Çelebi bin Derviş Muhammed Zilli, Evliya Çelebi Seyahatnamesi, haz. Orhan Şaik Gökyay ve Hey'et, İstanbul 1996, c. I, s. 204).

${ }^{28}$ Piyale Paşa'nın Vakfiyeleri, EV.VKF, 4/34; VGM A.D, nr. 573, s. 111-115; Şah Sultan Vakfiyesi'nin Osmanlı Türkçesi Tercümesi, EV.VKF, 9/20; Vakfiyenin Türkçe Tercümesi nr. 1993, s. 11-17; Şemsi Paşa Vakfiyesi, VGMA. D, nr. 1489; nr. 456, s. 105-122.
}

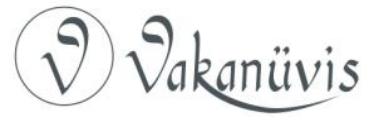


olmadığından, toplamda yirmi beş tekkenin beslenme ihtiyacının nasıl karşılandığı bilinmemektedir.

\section{2-) Tekkelerin Beslenme İmkanlarından Kimler Yararlanıyordu?}

Tekkelerin sağladığı beslenme imkanlarından istifade eden kişiler sadece tekkede sakin olan şeyh ve dervişler değildi. Bunların dışında tekkede konaklayan misafirler, mübarek gün ve gecelerde tekkeye gelen kişiler de tekkede yapılan yemeklerden istifade ediyordu. Dolayısıyla tekkeler geniş toplumsal kesimlerle ilişki kurmuş, tekkede farklı toplumsal kesimlere mensup çok sayıda insan buluşmuş oluyordu. Osmanlı tasavvuf ve tekke kültüründe tekkelerin kurumsal işleyişini belirleyen çeşitli gelenek ve teâmüller vardı. Ancak bu teâmül ve geleneklerle birlikte tekke banilerinin tercihleri de oldukça etkiliydi. Bâni tekkenin inşası ve faaliyetlerine başlaması sürecinde çeşitli gelirler tahsis eder, bu gelirlerden kimlerin ne ölçüde ve ne şekilde yararlanabileceğini belirlerdi. Tekkede ne tür yemekler pişirileceği ve bunlardan kimlerin ne ölçüde yararlanacağı da yerleşik gelenek, teâmül ve vâkıfın tercihleri doğrultusunda belirlenirdi ${ }^{29}$.

\section{Tekke Sakinleri}

Tekkelerde pişirilen yemeklerden istifade eden kişilerin başında tekke görevlileri gelirdi. Bütün tekkelerde bulunan şeyh ve dervişanın yanında bazen zakirbaşı, evradhan, ferraş, kayyum ve bevvab gibi görevliler de bulunurdu. Tekke yaşamında şeyh ve dervişler asıl aktörlerdi. Onlar olmadan tekke hayatı düşünülemezdi. Arşiv belgelerinde dervişlerin yaşamına ilişkin nispeten az bilgiye rastlanılırken, şeyhlerin sahip olması gereken nitelikler ve bu niteliklere uygun olarak görevleri daha detaylı bir şekilde anlatılmıştır. Hatta tekkenin ilk şeyhinin kim olacağı da bazen tayin edilmektedir. Bir başka deyişle, bani tekkesini hususi bir şeyh için yaptırarak, daha en baştan

\footnotetext{
${ }^{29}$ Osmanlı tekkeleri ve tekke yaşantısı için bakınız: M.B. Tanman, İstanbul Tekkelerinin Mimari ve Süsleme Özellikleri, Tipoloji Denemeleri, İstanbul Üniversitesi Sosyal Bilimler Enstitüsü, Basılmamış Doktora Tezi, İstanbul 1990; Öngören, age; N. Clayer, "Tekke" In Encyclopedia of Islam, Second ed., Leiden 2000, vol. 10, pp. 415-417; N. Clayer, "Life in An Istanbul Tekke in the Eighteenth and Nineteenth Centuries According to A "Menakıbname" of the Cerrahi Dervishes" The Illumunated Table, The Prosperous House, Food and Shelter in Ottoman Material Culture, ed. S. Faroqhi, C. Neumann, Würzburg 2003, s. 219-235.
}

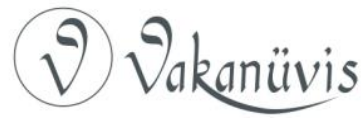


şeyhi belirlemektedir. Böylece tekkenin günlük işleyişindeki ruhani lider tayin edilmiş olmaktadır.

Şeyhlere göre haklarında daha az bilgi olmasına rağmen dervişlere dair de çeşitli bilgilere sahibiz. Onlar şeyhlerden sonra tekke yaşamının en önemli kahramanları, şeyhin yanında tekkede ikamet eden tasavvuf erbabıydı. Dervişler şeyhin yanında geçirdikleri zaman zarfında terbiye ve eğitimlerini tamamlayıp, bazen kendi tekkelerinde, bazen de bir başka tekkede seccadenişin görevini üstlenmektedirler. Henüz seyri sülukunu tamamlayamayan bir derviş ise tekkede kendine ayrılan hücresinde ikamet ederek tarikatının gerektirdiği zikir, tevhid, halvet gibi yükümlülüklerini yerine getiriyordu. Vakfiyelerde, vakıf belgelerinde ve yahut muhasebe defterlerinde derviş sayısı kayıtlıdır ${ }^{30}$. Mesela Şah Sultan Tekkesi'nde on beş derviş, ayrıca bir zakirbaşı, bir de evrâdhan vardı. Mehmed Ağa Tekkesi'nde ise içlerinden biri serzakir olan on iki derviş ${ }^{31}$, Atik Valide Tekkesi'nde ise otuz iki derviş

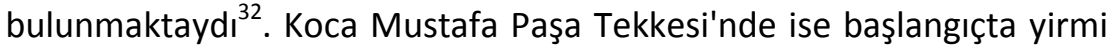
derviş varken, daha sonra sayı yirmi altıya çıktı ${ }^{33}$. Atik Ali Paşa Tekkesi vakfiyesinde ise yemek meselesi genel hatlarıyla anlatılmış, sayı zikredilmemişti ${ }^{34}$.

Bazı tekkelerde dervişler yemek yapma işini üstlenmişti. Mesela Ramazan Efendi Tekkesi'nde yemek pişirme işi dervişlere verilmişti ${ }^{35}$. Soğukkuyu Tekkesi'nde ise belirtilen zamanda yemek pişirmesi için görevlendirilen bir aşçıdan bahsedilmekle beraber, aynı belgenin bir başka yerinde tekke hücrelerinde ikamet eden dervişlerin yemek pişirmeleri için matbah ve yemekhanenin yapıldığı anlatılmaktadır. Bu durum Soğukkuyu Tekkesi'ndeki aşçının dervişlerden biri olabileceği ihtimalini akla getirmektedir ${ }^{36}$.

\footnotetext{
${ }^{30}$ Tekke görevlileri hakkında geniş bilgi için bakınız: Bölükbaşı, agt, s. 67-91.

${ }^{31}$ Şah Sultan Vakfiyesi'nin Osmanlı Türkçesi Tercümesi, EV.VKF, 9/20; Vakfiyenin Türkçe Tercümesi nr. 1993, s. 11-17; Habeşi Mehmed Ağa Vakfiyesi, TSMK, Emanet Hazinesi, nr. 3028.

${ }^{32}$ Nurbanu Sultan Vakfiyesi'nin Türkçesi, VGMA. D, nr. 1766, s. 166.

${ }^{33}$ MAD.d, nr. 1603; nr. 5918; Barkan ve Ayverdi, age, s. 369.

${ }^{34}$ Atik Ali Paşa Vakfiyesi, Süleymaniye, Esad Efendi, nr. 3673, vr. 18b-23a.

${ }^{35}$ Hüsrev Kethüda Vakfiyesi, VGMA.D, nr. 1592, s. 1-40.

${ }^{36}$ Piri Mehmed Paşa'nın Vakfiyeleri, VGMA. D, nr. 747, s. 178-181; s. 466-475; s. 481501; Vakfiyelerin Türkçeleri; VGMA. D, nr. 1991, s. 165-276.
}

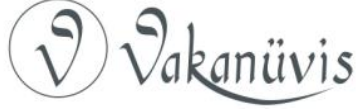




\section{Mübarek Gün ve Gecelerde Yapılan İkramlardan Yararlananlar}

Günlük yemek ihtiyaçlarını tekkenin matbahından ya da tekkenin içinde bulunduğu külliyenin imaretinden karşılayan şeyh ve dervişler, mübarek gün ve gecelerde daha leziz ve özel yemeklerle donatılmış sofralara oturmaktaydılar. Bu durum hem kendi matbahı olan tekkeler, hem de mensup oldukları külliye içindeki imaretten istifade eden tekkeler için geçerliydi. Mübarek gün ve gecelerde dervişan dışında farklı toplumsal kesimlerden kimseler de tekkede yapılan ikramlardan faydalanıyordu.

Kendi matbahı olan tekkelerden Hacı Kadın, Mehmed Ağa, Merkez Efendi ve Eyüp'teki Şah Sultan tekkelerinin vakfiyelerinde kandillerde, bayramlarda, aşure gününde, Ramazan gecelerinde ne tür ve ne kadar yemek yapılacağı açıklanmaktadır. Merkez Efendi ve Eyüp Şah Sultan tekkelerinde Mevlid kandilinde altı yüz, Berat ve Regaib kandillerinde dört yüz, Ramazan ve Kurban bayramlarında yüz ellişer akçelik yemek yapılıyordu. Ayrıca aşure gününde aşure pişirilmesi vakfiyede şart koşulmuştu. Yapılan yemeklerden dervişler ve tekkeye gelen sair fukara istifade edecekti. Bahsedilen gün ve gecelerde tekkeye gelen gidenler sayesinde, tarikatların toplumsal etkisi artmaktaydı. Bu mübarek gün ve gecelerde yemek için ayrılan meblağ günlük yemek tahsisatına göre çok yüksek olduğu için tekke ziyaretçileri ve yemek için gelen çevredeki fukara sayısı oldukça fazlaydı. Merkez Efendi ve Eyüp Şah Sultan tekkelerinde günlük yemek masrafı için yirmi beş akçe ayrıldığı hatırlanırsa kandil ve bayram günleri için yapılan tahsisatının ne kadar yüksek olduğu görülür. Mevlid kandili için ayrılan para günlük yemek tahsisatının yirmi dört katı, Berat ve Regaip kandili için ayrılan meblağ ise on altı katıydı ${ }^{37}$.

Merkez Efendi ve Şah Sultan (Eyüp) tekkeleri ile karşılaştıııldığında günlük yemek masrafı daha düşük olan ancak mübarek gün ve gecelerde onlarla yarışacak düzeyde olan $\mathrm{Hacı}$ Kadın Tekkesi'de de birçok kişiye yemek dağıtılmaktaydı. Regaip, Berat ve Kadir geceleri yapılacak yemekler ve Muharrem ayında aşure pişirilmesi için beş yüzer akçe, toplamda mübarek gün ve geceler için iki bin akçe

37 Şah Sultan Vakfiyesi'nin Osmanlı Türkçesi Tercümesi, EV.VKF, 9/20; Vakfiyenin Türkçe Tercümesi, VGMA.D, nr. 1993, s. 11-17.

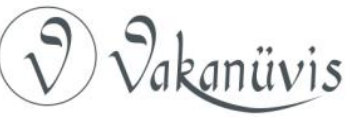


harcanacağı Hacı Kadın adına kayıtlı vakfiyede belirtilmiştir ${ }^{38}$. Mehmed Ağa Tekkesi'nin matbahında ise muharrem ayında beş yüz akçelik aşure pişirilecek; Berat, Miraç ve Kadir gecelerinde iki yüz akçelik helva yapılacaktı. Yapılan bu yiyeceklerden sadece tekkedeki dervişana değil, külliye içinde yer alan darülhadis görevlilerine ve Hoca Rüstem'deki medrese ve mektep öğrencilerine de dağıtılacaktı ${ }^{39}$.

Mensup olduğu külliyenin imaretinden faydalanan tekkelerde de mübarek gün ve gecelerde dervişan ve konuklar için zengin sofralar kuruluyordu. Mesela Atik Ali Paşa vakfiyesinde imarette pişirilen yemeklerin Cuma günleri ve mübarek gecelerde daha leziz olmasına dikkat edilmesi gerektiği özellikle vurgulanmaktaydı. Atik Ali Paşa'nın Vakfiyesi'nde bu durum şöyle izah edilmekteydi: Bugünlerde öğlenleri buğday, akşamları leziz yemekler pişirilecek. Her gelene bu yemeklerden verilecek. Öğlen ve akşam yemekleri için 50 okka et alınacak. Yarısı öğlen; diğer yarısı akşam pişirilecek. Ramazan da ise hepsi akşamları pişirilecektir ${ }^{40}$. Koca Mustafa Paşa İmareti'nde ise aşure ayının ilk günü on beş okka aşure dağıtılması; Cuma ve Ramazan gecelerinde ise on beş okka yağın yemekler için kullanılması şart koşulmuştu ${ }^{41}$.

\section{Tekkede Konaklayan Misafirler}

Tekkelerde pişirilen yemeklerden istifade eden gruplardan biri de tekkede konaklayan misafirlerdi. Kendi matbahı olan tekkelerden ikisine ait vakıf belgesinde -Sinan Erdebili ve Kefevi Alaaddin Efendi tekkelerine ait vakfiyelerde- ve beslenme ihtiyacını külliye içindeki imaretten karşılayan tekkelerde misafir ağırlamadan söz edilmektedir.

Sinan Erdebili Tekkesi bir camiye sahip değildir. Dolayısıyla camitekke türündeki yapılara göre daha bağımsız, münzevi bir yapıdır. Sinan Erdebili Tekkesi'nde yirmi üç hücrenin dervişlerin iskânına sunulduğu; şeyhe ise alt katta bir oda, üst katta iki oda, bir mutfak, bir su kuyusu, mahzen ve keniften oluşan bir binanın tahsis edildiği

\footnotetext{
${ }^{38}$ Hacı Kadın/Mihrişah Hatun Vakfiyesi, VGMA.D, nr. 633, s. 29-31; Vakfiyenin Türkçesi, VGMA. D, nr. 2104, s. 315-318.

${ }^{39}$ Habeşi Mehmed Ağa Vakfiyesi, TSMK, Emanet Hazinesi, nr. 3028, vr. 81a.

${ }^{40}$ Atik Ali Paşa Vakfiyesi, Süleymaniye, Esad Efendi, nr. 3673, vr. 18b-23a.

${ }^{41}$ Canatar, age, s. 604.
}

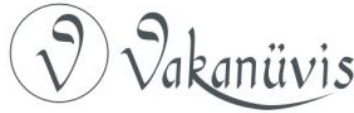


bilinmektedir. Hatta şeyhin ikâmetinde olan bu yere sonradan bir de hamam eklenmiştir. Tekkede kalan dervişlerin beslenme ihtiyacı için de kayda değer bir meblağ ayrılmıştır. Sinan Erdebili Tekkesi bir şeyh tarafından inşâ ettirilmiş sadece tekke özelliğine sahip mütevazı bir yapıdır. Bu yapıda, diğer cami-tekkelerdeki gibi günde beş vakit namaz kılmak için gelen bir cemaat yoktur. Dolayısıyla Sinan Erdebili Tekkesi sakinleri ibadet, zikir ve tevhid gibi işlerinin zamanını tanzim ederken daha rahat davranabilmekteydi. Bu durum tekkeye misafir kabulünü kolaylaştırmış olabilir. Vakfiyesinde tekkeye misafir olan kimselere nasıl muamele edileceğine dair ayrıntılar bulmak mümkündür. Misafir edilen kimseler ulema ve sâdatdan iseler üç gün üç gece, eğer avam-ı nasdan iseler ancak bir gün misafir edilebileceklerdi ${ }^{42}$. Tekkede konaklayacak misafirlere bu süre zarfında tekkede birtakım ikramlarda bulunulması, beslenme ihtiyaçlarının tekkede karşılanmış olması kuvvetle muhtemeldir. Kefevi Alaaddin Efendi Tekkesi'nde de misafirlerin konaklayabildiğinden Alaaddin Efendi adına kayıtlı vakıf belgesinde bahsedilmektedir. Ancak misafirler mutlaka şeyhten müsaade almalıydılar ${ }^{43}$.

Beslenme ihtiyacının külliye içindeki imaretten karşılandığı tekkelerden olan Atik Valide Tekkesi'ne ait vakfiyede de misafirlerden bahsedilmektedir. Ancak bu belgede, tekkede kalacak misafirlerin kimler olabileceğinden ya da ne kadar süre tekkede barınabileceklerinden bahsedilmez. Ancak tekkede misafirlerin oturdukları odalarda bulunan kandilerin yakılması için dört yüz on bir okka yağ tahsis edilmiştir ${ }^{44}$. Tekkede misafirlerin ikametine ayrılan odalar acaba hangileriydi diye düşünmek kaçınılmazdır. Atik Valide Tekkesi'nin otuz iki dervişi ve bir de şeyhi olduğu, dolayısıyla tekkenin otuz beş hücresinden otuz üçünün dervişlerin kullanımına uygun olduğu bilinmektedir. Kalan iki hücre ise tekkeye giriş için ayrılmıştır. Bütün hücreler, birisi hariç hepsi aynı büyüklüktedir. Tevhidhaneye açılan iki hücre vardır. Tevhidhane ile olan bağlantılarından ötürü bu iki

\footnotetext{
${ }^{42}$ Sinan Erdebili Vakfiyesi, VGMA. D, nr. 571, s. 1-2; Barkan ve Ayverdi, age, s. 3; Canatar, age, s. 3.

${ }^{43}$ Kefevi Alaaddin Efendi Tekkesi'ne ait bir vakıf belgesi için bakınız: AE. Sultan Bayezıd.II, 1/49.

44 Nurbanu Sultan Vakfiyesi, VGMA. D, nr. 2113, s. 281-309; Vakfiyenin Türkçesi, VGMA. D, nr. 1766, s. 136-170.
}

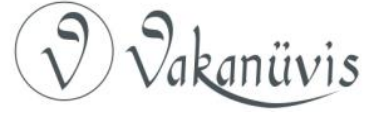


hücreden güneyde bulunan daha büyüktür ve bunlar diğerleri gibi alelâde derviş hücreleri değildir. Derviş odalarını mimari özelliklerine göre değerlendiren Tanman güneydekinin şeyh odası, diğerinin ise kahve ocağı olabileceğini söylemektedir ${ }^{45}$. Bu durumda derviş odalarının bir kısmının gerektiğinde misafirler için kullanılmış olabileceği akla gelmektedir.

Atik Valide Tekkesi menzil külliye özelliğine sahipti. Büyük hacı kafilelerinin, tüccarların ve doğu seferlerinde ordunun ilk ve son durağı olan Üsküdar'da bulunmaktaydı. Dolayısıyla Atik Valide Tekkesi'nin bu grupların uğrak yeri olduğu ve külliyenin içindeki imaretinde bahsedilen grupları ağırlamış olduğu söylenebilir ${ }^{46}$. Külliyenin imareti olduğuna göre, tekkede de misafirlerin ağırlanması, belli grupların özellikle burada misafir edilmek istenmesinden kaynaklanmış olabilir.

Osmanlı Devleti'nin kuruluş yıllarında zaviyelerin ve tekkelerin konaklama amacıyla kullanıldığı bilinmektedir. Bir yerin fethinin ardından buralarda zaviye ve tekkeler inşa edilmekteydi. Farklı dini gruplara hizmet eden bu yapılar, misafirlerin geceleyin konaklaması için odalara sahipti ${ }^{47}$. Osmanlı Devleti'nin kuruluş yıllarında zaviye ve tekke türündeki yapılara ek olarak, zaviyeli cami olarak bilinen, hem zaviye hem cami işlevine sahip yapılarda, gelen gidenlerin barındığını, zaviyenin yanında bir aşhane olduğunu bilmekteyiz. Elbette bu yapılar genelde belli bir tarikat şeyhi ve dervişlerine vakfedilmiş yapılar değildir. Dolayısıyla zaviye-cami türündeki yapılarda dervişler ve onlar için ayrılan hücreler yoktur. Zaviyeli camilerde şeyhin asli görevi tekkede konaklayan kişileri ağırlamaktı ${ }^{48}$.

45 M. B. Tanman, "Sinan'ın Mimarisi Tekkeler" Mimarbaşı Koca Sinan, Yaşadığı Çağ ve Eserleri, İstanbul 1988, s. 321.

${ }^{46}$ Ö. Özen, The Atik Valide Complex in Üsküdar, Boğaziçi Üniversitesi, Sosyal Bilimler Enstitüsü, Basılmamış Yüksek Lisans Tezi, İstanbul 2002, s. 67-68.

${ }^{47}$ i. Kolay, "Ottoman Caravanserais on Via Egnetia within the Borders of Present Day Turkey", Via Egnatia Revisited, Common Past, Common Future Netherlands 2009, s. 45-54.

${ }^{48}$ Mesela Çelebi Mehmed'in annesi Devlet Hatun'un Amasya Merzifon'da yaptırdığı zaviyeli camide, şeyh ve görevi şu şekilde tanımlanmaktaydı; "Oraya dindar, gelup gidenlere yer bulup konuklara mertebelerine göre onlara riayet ve itibâr eder bir kimse şeyh tayin olunur" (Devlet Hatun Vakfiyesi, VGMA. D, nr. 2134, s. 3). Bu konuda ayrıntılı bilgi için bakınız: Baha Tanman, "Bursa ve Çevresinde Erken Dönem Osmanlı

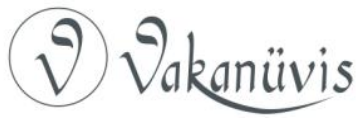


Osmanlı Devleti'nin kuruluş yıllarında inşaa edilen zaviyeli camilerin aksine XVI. yüzyılda payitaht i̇stanbul'da cami-tekkeler misafirhane işlevine sahip değildi. Cami işlevine sahip tekkeler konaklama imkânı sunmazken, sadece tekke özelliğine sahip Sinan Erdebili Tekkesi, Atik Valide Tekkesi ve mescit-tekke özelliği gösteren Kefevi Alaaddin Efendi Tekkesi gibi yapılar konaklama alanı olarak kullanılmaya devam etmiş görünmektedir. Bu dönemde kervansarayların sayısının artmış olması, konaklama için tekke ve zaviyelere olan ihtiyacı ortadan kaldırmış olmalıdır.

\section{3-) Tekkelerde Beslenmeyle İgili Birim ve Görevliler}

Vakfiyelerde tekke sakinlerinin beslenme tahsisatına, yemek yapımında kullanılacak malzemenin neler olduğuna, hangi yemeklerin pişirileceğine ve matbahta kullanılan alet edevata dair geniş bilgi verilmektedir. Ancak matbahların fiziki durumuna dair verilen bilgiler çok yetersizdir. Bunlarda genellikle matbahın tekke içindeki konumuna dair bilgilerdir.

Şah Sultan Tekkesi'nde matbah, selamlık, fırın, taamhane ve şeyh evi gibi birçok birimi aynı çatı altında toplayan bir yapının iç tarafındaki birimlerden biri olarak anlatılmıştır. Matbahın yakınında bulunan bir fırın ve aynı yapının dış kısmındaki taamhane onu tamamlayan diğer birimlerdi ${ }^{49}$. Balat Tekkesi'nde de, Şah Sultan Tekkesi'nde olduğu gibi selamlık türü bir yapı içinde matbah olduğunu tespit edebilmekteyiz. Matbah iki katlı selamlık türündeki yapının alt katında bulunmaktadır. Matbahın yanında ise kiler bulunmaktaydı. Matbahla ilgili birimlerin bir araya getirilmesi işlevsel açıdan doğru bir tercihtir ${ }^{50}$. Sokullu Mehmed Paşa Tekkesi'nde ise matbah tekke yapısının alt katında bulunmaktadır. Üst katta bulunan şeyh odasının altındaki yamuk planlı alanın matbah olduğu düşünülmektedir ${ }^{51}$.

Tarikat Yapıları" Bursa'da Dünden Bugüne Tasavvuf Kültürü, Yay. Ramiz Dara, İstanbul 2002, s. 254-264; Budak, agm, s. 21-36.

49 Şah Sultan Vakfiyesi'nin Osmanlı Türkçesi Tercümesi, EV.VKF, 9/20; Vakfiyenin Türkçe Tercümesi, VGMA.D, nr. 1993, s. 11-17.

${ }^{50}$ Ferruh Kethüda Vakfiyesi, VGMA. D, nr. 570, s. 57-60.

${ }^{51}$ Sokollu Mehmed Paşa Vakfiyesi, VGMA. D, nr. 572, s. 27-63; Vakfiyenin Türkçesi; VGMA. D, nr. 2104, s. 442-478; Tanman, Sinan'ın Mimarisi Tekkeler, s. 317.

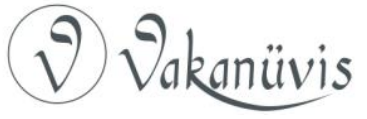


Matbahın tekke hücreleri yakınında olduğu örnekler de mevcuttu. Soğukkuyu Tekkesi'nde hücrelere bitişik birkaç birimden oluşan şeyhin ikametgahı ve bunun yakınında matbah ve taamhane bulunmaktaydı ${ }^{52}$. Doğancı Ahmed Paşa Tekkesi'nde ise altı hücreli tekkenin bir hücresi matbah olarak tahsis edilmiştir. Bir diğer hücrenin ise şeyhe ikametgâh olarak ayrıldığı belgede kayıtıdır ${ }^{53}$. Bu iki tekkede matbahın tekke yapısının en dıştaki birimi olduğu düşünülebilir.

Şah Sultan ve Balat Tekkeleri'nde selamlık birimleriyle bağlantılı olan matbah, Soğukkuyu ve Doğancı Ahmed Paşa Tekkeleri'nde ise özellikle tekke hücreleriyle bağlantılıdır. Nitekim Baha Tanman da tekkeleri matbahın konumuna göre üç gruba ayırmaktadır. Tanman'ın tasnifine göre ilk grupta mutfak ve hamam gibi ıslak zeminli birimlerin selamlıktan ayrı konumlandırıldığı tekkeler; ikinci grupta mutfağın ve selamlığa ait birimlerin birarada yer aldığı tekkeler; üçüncü grupta ise matbahın neredeyse bütün birimlerle bir bina içinde toplandığı, son dönem Osmanlı konutlarına benzeyen tekkeler yer alıyordu ${ }^{54}$. Dolayısıyla burada söz konusu edilen tekkeler Tanman'ın sınıflandırmasındaki ikinci gruba dahil edilebilir.

Vakfiyelerde tekkelerin beslenmeyle ilgili birimleri sayılırken matbah dışındaki birimlerden de söz edilir. Bunlar arasında fırın, kiler ve taamhaneler bulunmaktadır. Taamhaneler dervişlerin ve çevredeki fukaranın yemek yediği mekanlardır. Fırınlar ise ekmek pişirilen yerler olmalıdır. Piri Mehmed Paşa'nın vakfiyesinde Zeyrek'teki Soğukkuyu Tekkesi'nden bahsedilirken fırından da söz edilmektedir: "Şeyh Yahya'nın tarîkine mensûb sofiye tâifesine süknâ olmak üzere yirmi sekiz hücreden ibâretdir ve mezbûr hücrelere muttasıl olarak aralarında sofa bulunan tahtânî iki odayı ve bir fırını müştemil menzili mezbûr hângâhda şeyh ve mürşid olan kimseye süknâ olmak üzere vakf itdi" ${ }^{\prime 55}$. Burada bahsedilen iki alt kat oda, iki oda arasında bulunan bir sofa ve fırından oluşan menzil şeyhin iskân yeri olarak belirtilmiş.

Eyüp'teki Şah Sultan Tekkesi'nde yer alan fırın ise şu şekilde anlatılmıştır: "ve bir tarafı cami-i şerif merkume ve bir tarafı bahre ve

\footnotetext{
${ }^{52}$ Piri Mehmed Paşa Vakfiyeleri, VGMA.D, nr. 747, s. 178-181; s. 466- 475; 481-501.

53 Doğancı Ahmed Paşa Vakfiyesi, VGMA.D, nr. 503, s. 327-336.

${ }^{54}$ Baha Tanman, Kitchens of Ottoman Tekkes, s. 211-239.

${ }^{55}$ Piri Mehmed Paşa Vakfiyeleri, VGMA.D, nr. 747, s. 178-181; s. 466- 475; 481-501.
}

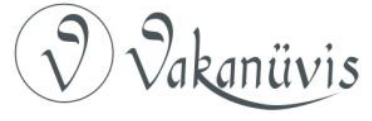


bir tarafı tarîk-i amme ve bir tarafı vakıfe-i müşarünileyhin mülküne müntehi olup içerisinde iki oda ve bir matbahı ve bir furunu, taşrasında iki odayı ve iki sofayı müştemil olan evleri zaviye-i merkumenin şeyhine vakfeylediler. Ve şart eylediler ki zikrolunan bir oda ve bir sofa şeyh-i mezbura selamlık ve bir oda, bir sofa dervişlere taamhane ola..." ${ }^{56}$. Şeyhe vakf edilen fırın tekkenin genel olarak ihtiyacını karşılamak için yapılmış gibi gözükmektedir. Nitekim şeyhe vakf edildiği söylenen yapının, bir oda ve bir sofadan oluşan kısmı da taamhane olarak tekke müridlerinin hizmetine sunulmuştur.

Kiler ise yemek pişirilirken ihtiyaç duyulan malzemelerin saklanması için kullanılmaktaydı. Balat'taki Ferruh Kethüda Tekkesi'ni oluşturan birimler içinde kiler de sayılmaktadır: "Taife-i süleha içün on bab hücreli ve bir fevkani cemiyethaneli ve sofalı ve cemiyethane altında bir kiları ve kilar yanında bir matbahı ve kütüphanelik ile maruf bir hücreyi müştemil bir zaviye-i latife bina eylediler..." ${ }^{157}$.

Vakıf belgelerinde yemek pişirme işinden sorumlu görevliler hakkındaki bilgiler ise kısıtlıdır. Tabbah ve ona ödenmesi gereken maaştan vakıf belgelerinde nadiren bahis vardır. Söz konusu kısıtlı bilgiler değerlendirildiğinde tabbaha ödenen maaşın genelde bir dervişe ödenen maaş kadar mütevazı miktarda olduğu görülür. Mesela mütevazı bir tekke olarak nitelendirebileceğimiz Balat Tekkesi'nde tabbaha günlük bir akçe verilmekteydi ${ }^{58}$. Matbahı olan tekkelerde tabbahın dışında yemek işiyle ilgilenen başka görevliler de bulunabilmekteydi. Küçük Ayasofya tekkesine ait vakfiyede bu görevliler yemekle ilgilenen şeyh, aşçı, ekmekçi, nakib, kilarcı, vekil-i harç, hizmetçi olarak sayılmaktadır ${ }^{59}$. İmarette çalışan görevliler ile tekke matbahındaki görevlilerin benzer olduğu görülmektedir. Yemek işiyle ilgilenen şeyh, yapılan işleri denetleyip gelen misafirleri karşılayarak onları ağırlamakta; aşçı (tabbah) yemekleri pişirip hazırlamakta; vekil-i harç yemek yapımı için gerekli malzemelerin

${ }^{56}$ Şah Sultan Vakfiyesi'nin Osmanlı Türkçesi Tercümesi, EV.VKF, 9/20; Vakfiyenin Türkçe Tercümesi nr. 1993, s. 11-17.

${ }^{57}$ Ferruh Kethüda Vakfiyesi, VGMA. D, nr. 570, s. 57-60; Vakfiyenin Türkçesi, VGMA. D, nr. 2111, 140-148.

${ }^{58}$ aynı vakfiye

${ }^{59}$ Hüseyin Ağa Vakfiyesi, TSMA.D, nr. 6900, nr. 6977.

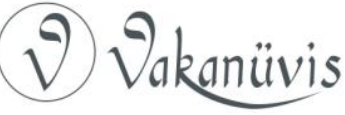


alınmasını sağlamakta, kilarcı alınan malzemeleri muhafaza etmekte, hizmetçi temizlik işlerini halletmekteydi ${ }^{60}$.

\section{4-) Genel Değerlendirme}

XVI. yüzyılda İstanbul'daki Halveti tekkeleri beslenme ihtiyacını karşıladıkları yer açısından kendi matbahı olan, beslenme ihtiyacını bağlı olduğu külliyenın imaretinden karşılayan ve beslenme ihtiyacını nereden karşıladığı bilinmeyen tekkeler olarak üç gruba ayrılabilirdi. Tekke matbahı görevlilerin çeşitliliği, günlük yemek tahsisatı, yemek pişirmede kullanılan alet edevat gibi hususlar açısından bir imareti anımsatan büyüklükte olabildiği gibi çok mütevazı boyutlarda da olabiliyordu. Tekke yapısının bağlı bulunduğu külliyenin imareti varsa tekke matbahına ihtiyaç duyulmamıştır.

Tekkelerin sağladığı beslenme imkanlarından faydalananlar sadece tekke mensupları veya tekke ile aynı külliye içinde bulunan cami, medrese ve mektep gibi kurumların görevlileri değildi. Tekkenin etrafında yaşayan fakir fukaraya, tekkede konaklayan misafirlere, özellikle mübarek gün ve gecelerde zengin veya fakir tekkeye gelen giden herkese ikramlarda bulunuluyordu. Bu durum çeşitli toplumsal kesimlerin tekkeyle irtibat kurmasını sağlıyordu. Tekke matbahının yanında beslenmeyle ilgili taamhane, kilar, fırın gibi birimlerin de bulunduğu tespit edilebilmektedir. Mevcut olan örnekler incelendiğinde beslenmeyle ilgili bu birimlerin tekkenin selamlık ünitesi birimlerinin yakınına yerleştirildiği görülmektedir.

\section{Kaynakça}

\section{a-) Tekkelere Ait Vakıf Belgeleri}

Atik Ali Paşa Vakfiyesi, Süleymaniye, Esad Efendi, nr. 3673, vr. 18b-23a.

Doğancı Ahmed Paşa Vakfiyesi, VGMA.D (Vakıflar Genel Müdürlüğü Arşivi Defter Tasnifi), nr. 503, s. 327-336.

Ferruh Kethüda (Balat Tekkesi) Vakfiyesi, VGMA. D, nr. 570, s. 57-60; Vakfiyenin Türkçesi, VGMA. D, nr. 2111, 140-148.

60 Zeynep Tarım Ertuğ, "İmâret" Türkiye Diyanet Vakfı İslam Ansiklopedisi, İstanbul 2000, c. XXII, s. 219-220.

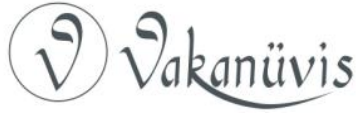


Habeşi Mehmed Ağa Vakfiyesi, TSMK (Topkapı Sarayı Müzesi Kütüphanesi), Emanet Hazinesi, nr. 3028.

Hacı Kadın/Mihrişah Hatun Vakfiyesi, VGMA.D, nr. 633, s. 29-31; Vakfiyenin Türkçesi, VGMA. D, nr. 2104, s. 315-318.

Hüseyin Ağa Vakfiyesi ve Küçük Ayasofya Tekkesi'ne ait diğer vakıf belgeleri, TSMA.D (Topkapı Sarayı Müzesi Arşivi Defter Tasnifi), nr. 6900, nr. 6977; nr. 3607/3; nr. 03665/4.

Hüsrev Kethüda (Ramazan Efendi Tekkesi) Vakfiyesi, VGMA.D, nr. 1592, s. 1-40.

İmarahor Illyas Bey Vakfiyesi, VGMA.D, nr. 747, s. 331-334.

Kefevi Alaaddin Efendi Tekkesi'ne ait vakıf belgeleri, BOA.AE (Başbakanlık Osmanlı Arşivi Ali Emiri Tasnifi). Sultan Bayezıd.II, 1/48; 1/49; Barkan ve Ayverdi, age, s. 312-314.

Koca Mustafa Paşa Tekkesi'ne ait vakıf belgeleri, Barkan ve Ayverdi, age, s. 366-369.

Koğacı Dede Tekkesi'ne ait vakıf belgeleri, Barkan ve Ayverdi, age, s. 296297.

Mimar Acem Ali Vakfiyeleri ve diğer vakıf belgeleri, Kunter, H. B., "Mimar Ali Bey'in Bilinmeyen İki Vakfiyesi", V. Türk Tarih Kongresi Bildirileri, Ankara 1960, s. 438-443; Barkan ve Ayverdi, age, s. 382-384.

Nurbanu Sultan (Atik Valide Tekkesi) Vakfiyesi, VGMA. D, nr. 2113, s. 281309; Vakfiyenin Türkçesi, VGMA. D, nr. 1766, s. 136-170.

Piri Mehmed Paşa Vakfiyeleri (Koruk ve Soğukkuyu Tekkeleri), VGMA.D, nr. 747, s. 178-181; s. 466- 475; 481-501.

Piyale Paşa'nın Vakfiyeleri, BOA. EV.VKF (Başbakanlık Osmanlı Arşivi Evkaf Vakfiyeler Evrakı), 4/34; VGM A.D, nr. 573, s. 111-115.

Sinan Erdebili Vakfiyesi, VGMA. D, nr. 571, s. 1-2.

Sokollu Mehmed Paşa Vakfiyesi, VGMA. D, nr. 572, s. 27-63, Vakfiyenin Türkçesi; VGMA. D, nr. 2104, s. 442-478.

Süleyman Ekmeleddin Tekkesi vakıf belgeleri, Barkan ve Ayverdi, age, s. 310-312; Canatar, age, s. 489.

Şah Sultan Vakfiyesi'nin Osmanlı Türkçesi Tercümesi (Merkez Efendi, Eyüp Şah Sultan ve Davutpaşa Tekkeleri), EV.VKF, 9/20; Vakfiyenin Türkçe Tercümesi nr. 1993, s. 11-17.

Şemsi Paşa Vakfiyesi, VGMA. D, nr. 1489; nr. 456, s. 105-122.

Yahya Kethüda Vakfiyesi, VGMA. D, nr. 633, s. 158-169; Vakfiyenin Türkçesi, VGMA. D, nr. 1967, s. 198-227.

\section{b-) Diğer Arşiv Belgeleri}

Devlet Hatun Vakfiyesi, VGMA. D, nr. 2134, s. 3.

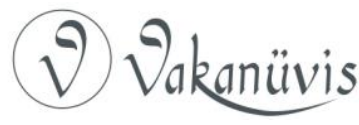


BOA. MAD.d (Başbakanlık Osmanlı Arşivi Maliyeden Müdevver Defterler Tasnifi), nr. 1603; nr. 5918.

\section{c-) Yararlanılan Diğer Kaynaklar}

Barkan, Ö. L. ve E. H. Ayverdi, 953 (1546) Tarihli Istanbul Vakıfları Tahrir Defteri, İstanbul 1970.

Bölükbaşı, Ayşe, XVI. Yüzyılda istanbul'daki Halveti Tekkeleri, İstanbul Teknik Üniversitesi, Fen Bilimleri Enstitüsü, Basılmamış Doktora Tezi, dan. Prof. Dr. İlknur Kolay, İstanbul 2015.

Bölükbaşı, Ayşe, "Halveti Tekkelerinin İnşasında Devlet İdarecilerinin Rolü" History Studies, Şerafettin Turan'a Armağan, Nisan 2014, cilt: 6, sayı: 3, s. 7187.

Budak, Ayşe, "Imaret Kavramı Üzerinden Erken Osmanlı Ters T Planlı Zaviyeleri ile Aşhanelerin İlişkisi: Osmanlı Aşhanelerinin Kökenine Dair Düşünceler" METU JFA 2016/1, (33:1) 21-36.

Canatar, Mehmet, Istanbul Vakıfları Tahrir Defteri 1009 (1600) Tarihli, İstanbul 2004.

Clayer, N., "Tekke" In Encyclopedia of Islam, Second ed., Leiden 2000, vol. 10, pp. 415-417.

Clayer, N., "Life in An Istanbul Tekke in the Eighteenth and Nineteenth Centuries According to A "Menakıbname" of the Cerrahi Dervishes" The Illumunated Table, The Prosperous House, Food and Shelter in Ottoman Material Culture, ed. S. Faroqhi, C. Neumann, Würzburg 2003, s. 219-235.

Evliya Çelebi bin Derviş Muhammed Zilli, Evliya Çelebi Seyahatnamesi, haz. Orhan Şaik Gökyay ve Hey'et, İstanbul 1996, c. I.

Ertuğ, Zeynep Tarım, "İmâret" Türkiye Diyanet Vakfı Islam Ansiklopedisi, İstanbul 2000, c. XXII, s. 219-220.

Eyice, Semavi, "ilk Osmanlı Devrinin Dini İctimai Bir Müessesesi: Zaviyeler ve Zaviyeli Camiler" istanbul Üniversitesi iktisat Fakültesi Mecmuası (23), İstanbul 1963, s. 1-80.

Gündüzöz, Güldane, "Osmanlı Tekke Mutfak Kültürü ve Mecmuâ-i Fevâid", Cumhuriyet Ilahiyat Dergisi, sayı: 20-2 (Aralık 2016), s. 175-205.

Kolay, i., "Ottoman Caravanserais on Via Egnetia within the Borders of Present Day Turkey", Via Egnatia Revisited, Common Past, Common Future Netherlands 2009, s. 45-54.

Mahmud Cemaleddin Hulvi (1993). Lemazat-ı Hulviyye ez Lemazat-ı Ulviyye (M. S. Tayşi, Haz.). İstanbul 1993.

Nev'izade Atâî, Hadaiku'l Hakaik fi Tekmileti'l-Şakaik, nşr. A. Özcan, İstanbul 1989.

Öngören, Reşat, Osmanlılarda Tasavvuf, Anadolu'da Sufiler Devlet ve Ulema (16. Yüzyıl), İstanbul 2000;

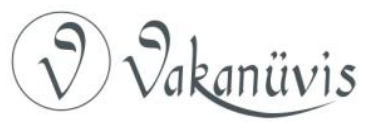


Özen, Ö., The Atik Valide Complex in Üsküdar, Boğaziçi Üniversitesi, Sosyal Bilimler Enstitüsü, Basılmamış Yüksek Lisans Tezi, İstanbul 2002.

Singer, Amy, "Evliya Çelebi on Imarets" Mamluks and Ottomans, Studies in Honour of Michael Winter, ed. by David J. Wasserstein and Ami Ayalon, London and New York 2006, s. 123-132.

Singer, Amy, "Imarets" The Ottoman World, ed. C. Woodhead, London 2012, s. 72-85.

Tanman, M. B., "Sinan'ın Mimarisi Tekkeler" Mimarbaşı Koca Sinan, Yaşadığı Çağ ve Eserleri, İstanbul 1988, s. s. 311-332.

Tanman, M. B., İstanbul Tekkelerinin Mimari ve Süsleme Özellikleri, Tipoloji Denemeleri, İstanbul Üniversitesi Sosyal Bilimler Enstitüsü, Basılmamış Doktora Tezi, ìstanbul 1990;

Tanman, M. B., "Bursa ve Çevresinde Erken Dönem Osmanlı Tarikat Yapıları" Bursa'da Dünden Bugüne Tasavvuf Kültürü, Yay. Ramiz Dara, İstanbul 2002, s. 254-264;

Tanman, M. B., "Kitchens of Ottoman Tekkes as Reflections of Imarets in Sufi Architecture", Feeding People Feeding Power, Imarets in the Ottoman Empire, ed. N.Ergin, C.K.Neumann, A.Singer, ìstanbul 2007, s. 211-239.

Yazıcı, Tahsin, Fetihten Sonra isstanbul'da illk Halvetî Şeyhleri: Çelebi Muhammed Cemaleddin, Sünbül Sinan ve Merkez Efendi, Istanbul Fetih Cemiyeti, 1956, 2, s. 87-113.

Yürekli, Z., The Sufi Convent of Sokullu Mehmed Pasha in Istanbul, Muqarnas, 20, 2003, s. 159-185.

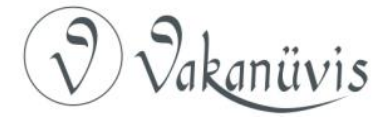




\section{Ek-I) XVI. Yüzyılda İstanbul'daki Halveti Tekkeleri ${ }^{61}$}

\begin{tabular}{|c|c|c|c|c|c|}
\hline & Tekkenin Adı & Bâni Adı & $\begin{array}{l}\text { Bâninin Mensup } \\
\text { Olduğu Sınıf }\end{array}$ & $\begin{array}{l}\text { Bâninin } \\
\text { Mensup } \\
\text { Olduğu Alt } \\
\text { Sınıf }\end{array}$ & $\begin{array}{l}\text { Tekkenin } \\
\text { Mensup } \\
\text { Olduğu } \\
\text { Halveti } \\
\text { Kolu }\end{array}$ \\
\hline 1 & $\begin{array}{l}\text { Küçük } \\
\text { Ayasofya }\end{array}$ & Hüseyin Ağa & $\begin{array}{l}\text { Saray ve } \\
\text { Çevresine Mensup }\end{array}$ & $\begin{array}{l}\text { Babüsaade } \\
\text { Ağası }\end{array}$ & Cemali \\
\hline 2 & $\begin{array}{l}\text { İmrahor ilyas } \\
\text { Bey }\end{array}$ & İmrahor ilyas Bey & $\begin{array}{l}\text { Saray ve } \\
\text { Çevresine Mensup }\end{array}$ & Mirahur & Cemali \\
\hline 3 & Atik Ali Paşa & Atik Ali Paşa & $\begin{array}{l}\text { Saray ve } \\
\text { Çevresine Mensup }\end{array}$ & Sadrazam & Cemali \\
\hline 4 & $\begin{array}{l}\text { Karabaş } \\
\text { Tekkesi }\end{array}$ & $\begin{array}{l}\text { Karabaş Mustafa } \\
\text { Ağa }\end{array}$ & $\begin{array}{l}\text { Saray ve } \\
\text { Çevresine Mensup }\end{array}$ & $\begin{array}{l}\text { Babüsaade } \\
\text { Ağası }\end{array}$ & Cemali \\
\hline 5 & Piyale Paşa & Piyale Paşa & $\begin{array}{l}\text { Saray ve } \\
\text { Çevresine Mensup }\end{array}$ & Kaptan Paşa & Cemali \\
\hline 6 & Yahya Kethüda & Yahya Kethüda & $\begin{array}{l}\text { Saray ve } \\
\text { Çevresine Mensup }\end{array}$ & $\begin{array}{l}\text { Sadrazam } \\
\text { Kethüdası }\end{array}$ & Cemali \\
\hline 7 & $\begin{array}{l}\text { Sokullu } \\
\text { Mehmed Paşa }\end{array}$ & $\begin{array}{l}\text { Sokullu Mehmed } \\
\text { Paşa }\end{array}$ & $\begin{array}{l}\text { Saray ve } \\
\text { Çevresine Mensup }\end{array}$ & Sadrazam & Cemali \\
\hline 8 & $\begin{array}{l}\text { Koca Mustafa } \\
\text { Paşa }\end{array}$ & Koca Mustafa Paşa & $\begin{array}{l}\text { Saray ve } \\
\text { Çevresine Mensup }\end{array}$ & Kapıcıbaşı & Sünbüli \\
\hline 9 & Acem Ali & $\begin{array}{l}\text { Mimarbaşı Acem } \\
\text { Ali }\end{array}$ & $\begin{array}{l}\text { Saray ve } \\
\text { Çevresine Mensup }\end{array}$ & Mimarbaşı & Sünbüli \\
\hline 10 & $\begin{array}{l}\text { Davutpaşa Şah } \\
\text { Sultan }\end{array}$ & Şah Sultan & $\begin{array}{l}\text { Saray ve } \\
\text { Çevresine Mensup }\end{array}$ & Padişah Kızı & Sünbüli \\
\hline 11 & $\begin{array}{l}\text { Eyüp Şah } \\
\text { Sultan }\end{array}$ & Şah Sultan & $\begin{array}{l}\text { Saray ve } \\
\text { Çevresine Mensup }\end{array}$ & Padişah Kızı & Sünbüli \\
\hline 12 & Merkez Efendi & Şah Sultan & $\begin{array}{l}\text { Saray ve } \\
\text { Çevresine Mensup }\end{array}$ & Padişah Kızı & Sünbüli \\
\hline 13 & $\begin{array}{l}\text { Drogoman } \\
\text { Yunus Bey }\end{array}$ & Tercüman Yunus & $\begin{array}{l}\text { Saray ve } \\
\text { Çevresine Mensup }\end{array}$ & $\begin{array}{l}\text { Divan } \\
\text { Tercümanı }\end{array}$ & Sünbüli \\
\hline 14 & Balat & Ferruh Kethüda & $\begin{array}{l}\text { Saray ve } \\
\text { Çevresine Mensup }\end{array}$ & $\begin{array}{l}\text { Sadrazam } \\
\text { Kethüdası }\end{array}$ & Sünbüli \\
\hline 15 & Balçık & $\begin{array}{l}\text { Gazi Tiryaki Hasan } \\
\text { Paşa }\end{array}$ & $\begin{array}{l}\text { Saray ve } \\
\text { Çevresine Mensup }\end{array}$ & Vezir & Sünbüli \\
\hline 16 & $\begin{array}{l}\text { Keşfi Cafer } \\
\text { Efendi }\end{array}$ & Perizad Hatun & $\begin{array}{l}\text { Saray ve } \\
\text { Çevresine Mensup }\end{array}$ & $\begin{array}{l}\text { Vezir } \\
\text { Hanımı }\end{array}$ & Sünbüli \\
\hline 17 & Hacı Kadın & $\begin{array}{l}\text { Hacı Kadın } \\
\text { (Mihrişah Hatun) }\end{array}$ & $\begin{array}{l}\text { Saray ve } \\
\text { Çevresine Mensup }\end{array}$ & Vezir Kızı & Sünbüli \\
\hline 18 & Atik Valide & Nurbanu Sultan & $\begin{array}{l}\text { Saray ve } \\
\text { Çevresine Mensup }\end{array}$ & $\begin{array}{l}\text { Valide } \\
\text { Sultan }\end{array}$ & Şabani \\
\hline 19 & Şemsi Paşa & Şemsi Ahmed Paşa & $\begin{array}{l}\text { Saray ve } \\
\text { Çevresine Mensup }\end{array}$ & Musahip & Şabani \\
\hline 20 & Mehmed Ağa & Mehmed Ağa & $\begin{array}{l}\text { Saray ve } \\
\text { Çevresine Mensup }\end{array}$ & $\begin{array}{l}\text { Darüssaade } \\
\text { Ağası }\end{array}$ & Şabani \\
\hline
\end{tabular}

${ }^{61}$ Bölükbaşı, agt. 


\begin{tabular}{|c|c|c|c|c|c|}
\hline 21 & Musalla & Ferhad Paşa & $\begin{array}{l}\text { Saray ve } \\
\text { Çevresine Mensup }\end{array}$ & Vezir & Ramazani \\
\hline 22 & $\begin{array}{l}\text { Hüsameddin } \\
\text { Uşşaki }\end{array}$ & III. Murad & $\begin{array}{l}\text { Saray ve } \\
\text { Çevresine Mensup }\end{array}$ & Padişah & Uşşaki \\
\hline 23 & $\begin{array}{l}\text { Muhsine } \\
\text { Hatun }\end{array}$ & Muhsine Hatun & $\begin{array}{l}\text { Saray ve } \\
\text { Çevresine Mensup }\end{array}$ & - & Gülşeni \\
\hline 24 & Soğukkuyu & Piri Mehmed Paşa & $\begin{array}{l}\text { Saray ve } \\
\text { Çevresine Mensup }\end{array}$ & Sadrazam & Karamani \\
\hline 25 & Koruk & Piri Mehmed Paşa & $\begin{array}{l}\text { Saray ve } \\
\text { Çevresine Mensup }\end{array}$ & Sadrazam & Karamani \\
\hline 26 & $\begin{array}{l}\text { Sütlüce } \\
\text { Mahmud Ağa }\end{array}$ & $\begin{array}{l}\text { Piri Mehmed } \\
\text { Paşa/Mahmud Ağa }\end{array}$ & $\begin{array}{l}\text { Saray ve } \\
\text { Çevresine Mensup }\end{array}$ & - & Karamani \\
\hline 27 & Pazar & $\begin{array}{l}\text { Katip Mehmed } \\
\text { Efendi }\end{array}$ & $\begin{array}{l}\text { Saray ve } \\
\text { Çevresine Mensup }\end{array}$ & Katip & Sinani \\
\hline 28 & Nalinci Dede & III. Murad & $\begin{array}{l}\text { Saray ve } \\
\text { Çevresine Mensup }\end{array}$ & Padişah & ? \\
\hline 29 & Cafer Paşa & Cafer Paşa & $\begin{array}{l}\text { Saray ve } \\
\text { Çevresine Mensup }\end{array}$ & Vezir & ? \\
\hline 30 & $\begin{array}{l}\text { Doğancı } \\
\text { Ahmed Paşa }\end{array}$ & $\begin{array}{l}\text { Doğancı Ahmed } \\
\text { Paşa }\end{array}$ & $\begin{array}{l}\text { Saray ve } \\
\text { Çevresine Mensup }\end{array}$ & Vezir & ? \\
\hline 31 & $\begin{array}{l}\text { Çizmeciler } \\
\text { Tekkesi }\end{array}$ & Bedreddin Ağa & $\begin{array}{l}\text { Saray ve } \\
\text { Çevresine Mensup }\end{array}$ & $\begin{array}{l}\text { Saray } \\
\text { Hademesi }\end{array}$ & ? \\
\hline 32 & $\begin{array}{l}\text { Celalzâde } \\
\text { Mustafa }\end{array}$ & $\begin{array}{l}\text { Nişancı Celalzâde } \\
\text { Mustafa }\end{array}$ & $\begin{array}{l}\text { Saray ve } \\
\text { Çevresine Mensup }\end{array}$ & Nişancı & $?$ \\
\hline 33 & $\begin{array}{l}\text { Kefevi } \\
\text { Alaaddin } \\
\text { Efendi }\end{array}$ & $\begin{array}{l}\text { Kefevi Alaaddin } \\
\text { Efendi }\end{array}$ & Şeyh & - & Sünbüli \\
\hline 34 & $\begin{array}{l}\text { Süleyman } \\
\text { Ekmeleddin }\end{array}$ & $\begin{array}{l}\text { Süleyman } \\
\text { Ekmeleddin/Sofular }\end{array}$ & Şeyh & - & Sünbüli \\
\hline 35 & Koğacı Dede & $\begin{array}{l}\text { Şeyh Sevündük } \\
\text { Şücaaddin Efendi }\end{array}$ & Şeyh & - & Sünbüli \\
\hline 36 & Sinan Erdebili & Sinan Erdebili & Şeyh & - & Sünbüli \\
\hline 37 & Altuncuzade & Sarhoş Bali Efendi & Şeyh & - & Cemali \\
\hline 38 & Durmuş Dede & Şeyh Hasan Zarifi & Şeyh & - & Gülşeni \\
\hline 39 & Nakkaş Baba & Nakkaş Baba & Şeyh & - & Karamani \\
\hline 40 & Ümmi Sinan & Ümmi Sinan & Şeyh & - & Sinani \\
\hline 41 & Nasuh Dede & Nasuh Dede & Şeyh & - & Sinani \\
\hline 42 & Emirler & $\begin{array}{l}\text { Şeyh Seyyid } \\
\text { Nizamoğlu }\end{array}$ & Şeyh & - & Sinani \\
\hline 43 & Hacı Evhad & Hacı Evhad & Esnaf & Kasap & Sünbüli \\
\hline 44 & $\begin{array}{l}\text { Ramazan } \\
\text { Efendi }\end{array}$ & Hüsrev Kethüda & Esnaf & $\begin{array}{l}\text { Bezzasistan } \\
\text { Kethüdası }\end{array}$ & Ramazani \\
\hline 45 & Aydınoğlu & $\begin{array}{l}\text { Saçlı Emir Tebrizli } \\
\text { Muhyiddin Efendi }\end{array}$ & Ulema & - & $?$ \\
\hline
\end{tabular}




\section{Ek-II) XVI. Yüzyılda İstanbul'daki Halveti Tekkelerinde Beslenme İhtiyacının Karşılanması ${ }^{62}$}

\begin{tabular}{|c|c|c|c|c|}
\hline \multicolumn{5}{|c|}{ Kendi Matbahı Olan Tekkeler } \\
\hline & Tekke adı & Yemek tahsisatı & Vakfedilen matbah eşyası & $\begin{array}{l}\text { Personel } \\
\text { ücreti }\end{array}$ \\
\hline 1 & $\begin{array}{l}\text { Kefevi } \\
\text { Alaaddin } \\
\text { Efendi }\end{array}$ & $\begin{array}{l}\text { Banisi tarafından değil, } \\
\text { fakat daha sonra başka } \\
\text { hayırseverler tarafından } \\
\text { yemek için bir miktar } \\
\text { para vakfedilmiştir }\end{array}$ & $\begin{array}{l}\text { Banisi tarafından değil, fakat } \\
\text { daha sonra başka bir } \\
\text { hayırsever tarafından } \\
\text { vakfedilmiş olan bir sini, bir } \\
\text { kazan; diğer bir kişi tarafından } \\
\text { vakfedilmiş olan yedi kazan, } \\
\text { beş sacayak, üç sini, on iki } \\
\text { sahan, bir tepsi }\end{array}$ & \\
\hline 2 & Balat & $\begin{array}{l}\text { Yemek için günlük on } \\
\text { akçe tahsis edilmiş; } \\
\text { ayrıca misafirler için } \\
\text { yılda üç müd pirinç, dört } \\
\text { kantar tereyağı, turşu, } \\
\text { peynir ve bal için günlük } \\
\text { altı akçe }\end{array}$ & $\begin{array}{l}\text { Bir büyük tencere; bir küçük, } \\
\text { üç büyük sahan; iki sofra, bir } \\
\text { yahni tepsisi, bir leğen, bir } \\
\text { ibrik, bir tava, bir hoşaf tası, } \\
\text { bir kebap tavası, bir kevgir, bir } \\
\text { kepçe, bir sini, iki bulgari sofra, } \\
\text { bir güğüm, bir kebap demiri, iki } \\
\text { sacayak, iki şamdan, bir satır, } \\
\text { bir büyük leğen }\end{array}$ & $\begin{array}{l}\text { Tabbah bir } \\
\text { akçe }\end{array}$ \\
\hline 3 & Hacı Kadın & $\begin{array}{l}\text { Günlük on üç akçe; } \\
\text { ayrıca mübarek gün ve } \\
\text { gecelerden Regayib, } \\
\text { Berat ve Kadir geceleri } \\
\text { ile aşure zamanında } \\
\text { kullanılmak üzere beş } \\
\text { yüzer akçeden toplam iki } \\
\text { bin akçe }\end{array}$ & & \\
\hline 4 & Koruk & $\begin{array}{l}\text { Günlük yirmi akçe iken, } \\
\text { vakfın tesisinden dört yıl } \\
\text { sonra yirmi iki akçe } \\
\text { olmuştur }\end{array}$ & & $\begin{array}{l}\text { Tabbah bir } \\
\text { buçuk akçe }\end{array}$ \\
\hline 5 & $\begin{array}{l}\text { Koğacı } \\
\text { Dede }\end{array}$ & & Yirmi sini, yirmi sahan & \\
\hline 6 & Küçük & Günlük bir kile buğday & & Tabbah üç, \\
\hline
\end{tabular}

62 Tabloda sadece hakkında vakıf belgesi olan ve söz konusu belgede beslenme ihtiyacının nasıl karşılandığına dair bilgi verilen tekkeler gösterilmiştir. Tabloda yer alan tekkelere ait vakıf belgelerinin tam listesi kaynakçada verilmiştir. Söz konusu liste aynı zamanda bu tabloda yer alan bilgilerinde kaynağıdır.

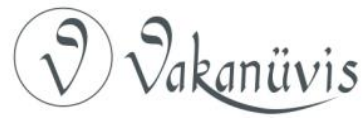




\begin{tabular}{|c|c|c|c|}
\hline & Ayasofya & $\begin{array}{l}\text { ve sekiz okka koyun eti } \\
\text { tahsis edilmişti. } \\
\text { Buğdayın bir kısmı } \\
\text { ekmek, bir kısmı da } \\
\text { çorba pişirilmesi için } \\
\text { kullanılacaktı. Her gün } \\
\text { seksen ekmek } \\
\text { pişirilecekti. Vakfiyede } \\
\text { günde bir öğün yemek } \\
\text { verilmesi şart } \\
\text { koşulmuştu. Ancak diğer } \\
\text { harcamalar yapıldıktan } \\
\text { sonra fazla para kalırsa } \\
\text { öğün sayısı ikiye } \\
\text { çıkarılabilecekti. }\end{array}$ & $\begin{array}{l}\text { yemek } \\
\text { şeyhi üç, } \\
\text { ekmekçi } \\
\text { üç, nakib } \\
\text { iki, kilerci } \\
\text { iki, buğday } \\
\text { döğen ve } \\
\text { kap kaçak } \\
\text { yıkayan } \\
\text { kişi bir } \\
\text { buçuk ve } \\
\text { vekil-i harç } \\
\text { bir buçuk } \\
\text { akçe } \\
\text { alacaktı }\end{array}$ \\
\hline 7 & $\begin{array}{l}\text { Mehmet } \\
\text { Ağa }\end{array}$ & $\begin{array}{l}\text { Ayda iki kile pirinç } \\
\text { verilmesi, bunun } \\
\text { Ramazan ayında bir } \\
\text { buçuk kile arttırılması; } \\
\text { bir kile mercimek veya } \\
\text { buğday; yıllık otuz okka } \\
\text { bal ve otuz yedi okka } \\
\text { revgan-ı sade, dört yüz } \\
\text { seksen akçelik et; yıllık } \\
\text { elli çeki odun, iki kile tuz } \\
\text { ve iki kile nohut temin } \\
\text { edilmesi şart } \\
\text { koşulmuştu. Ayrıca aşure } \\
\text { vaktinde beş yüz akçelik } \\
\text { aşure pişirilmesi; Berat } \\
\text { ve Kadir gecesi gibi bazı } \\
\text { mübarek gün ve } \\
\text { gecelerde iki yüz akçelik } \\
\text { helva yapılması da kayda } \\
\text { geçirilmişti }\end{array}$ & \\
\hline 8 & $\begin{array}{l}\text { Merkez } \\
\text { Efendi }\end{array}$ & $\begin{array}{l}\text { Beslenme için günlük } \\
\text { yirmi beş akçe tahsis } \\
\text { edilmişti. Mevlid } \\
\text { kandilinde altı yüz, Berat } \\
\text { ve Regaib kandillerinde } \\
\text { dört yüz, Ramazan ve } \\
\text { Kurban bayramlarında } \\
\text { yüz ellişer akçelik yemek } \\
\text { yapılacaktı. Ayrıca aşure } \\
\text { günüde aşure pişirilmesi } \\
\text { vakfiyede şart } \\
\text { koşulmuştu }\end{array}$ & \\
\hline
\end{tabular}




\begin{tabular}{|c|c|c|c|c|}
\hline 9 & $\begin{array}{l}\text { Mimar } \\
\text { Acem }\end{array}$ & $\begin{array}{l}1524 \text { tarihli vakfiyede } \\
\text { ayda otuz beş akçe; } \\
1536 \text { tarihli vakfiyede ise } \\
\text { elli akçe olarak } \\
\text { belirlenmişti }\end{array}$ & & \\
\hline 10 & $\begin{array}{l}\text { Ramazan } \\
\text { Efendi }\end{array}$ & $\begin{array}{l}\text { Yemek tahsisatından } \\
\text { vakfiyede } \\
\text { bahsedilmemiştir. } \\
\text { Sadece aşçının yevmiyesi } \\
\text { gösterilmiştir }\end{array}$ & & $\begin{array}{l}\text { Tabbah } \\
\text { günlük bir } \\
\text { akçe }\end{array}$ \\
\hline 11 & $\begin{array}{l}\text { Sinan } \\
\text { Erdebili }\end{array}$ & $\begin{array}{l}\text { Yemek tahsisatı } \\
\text { vakfiyede tasrih } \\
\text { edilmemiştir. Diğer } \\
\text { zaruri masraflar } \\
\text { ödendikten sonra arta } \\
\text { kalan paranın tekkenin } \\
\text { yemek ihtiyacı için sarf } \\
\text { edilmesi kaydedilmiştir. }\end{array}$ & Üç kazan, sahan ve sacayak & \\
\hline 12 & Soğukkuyu & Günlük yirmi beş akçe & & $\begin{array}{l}\text { Tabbah } \\
\text { günlük iki } \\
\text { akçe }\end{array}$ \\
\hline 13 & $\begin{array}{l}\text { Süleyman } \\
\text { Ekmeleddin }\end{array}$ & $\begin{array}{l}\text { Yemek tahsisatı } \\
\text { vakfiyede tasrih } \\
\text { edilmemiştir. Yeterli } \\
\text { miktarda yemek } \\
\text { pişirilmesi, mütevellinin } \\
\text { uygun göreceği şekilde } \\
\text { dağıtılması şart } \\
\text { koşulmuştur. }\end{array}$ & & $\begin{array}{l}\text { Tabbah } \\
\text { ayda elli } \\
\text { akçe }\end{array}$ \\
\hline 14 & $\begin{array}{l}\text { Sokullu } \\
\text { Mehmet } \\
\text { Paşa }\end{array}$ & $\begin{array}{l}\text { Vakfiyede beslenme } \\
\text { meselesinden } \\
\text { bahsedilmemektedir. } \\
\text { Ancak mevcut planlarda } \\
\text { tekkenin sol tarafta } \\
\text { bulunan alt kat } \\
\text { hücrelerinin yan } \\
\text { tarafında bir matbah ve } \\
\text { tabhane bulunmaktadır. }\end{array}$ & & \\
\hline 15 & $\begin{array}{l}\text { Eyüp Şah } \\
\text { Sultan }\end{array}$ & $\begin{array}{l}\text { Beslenme için günlük } \\
\text { yirmi beş akçe tahsis } \\
\text { edilmişti. } \\
\text { kandilinde altı yüz, Berat } \\
\text { ve Regaib kandillerinde } \\
\text { dört yüz, Ramazan ve }\end{array}$ & & \\
\hline
\end{tabular}




\begin{tabular}{|c|c|c|c|c|}
\hline & & $\begin{array}{l}\text { Kurban bayramlarında } \\
\text { yüz ellişer akçelik yemek } \\
\text { yapılacaktı. Ayrıca aşure } \\
\text { günüde aşure pişirilmesi } \\
\text { vakfiyede } \\
\text { koşulmuştu. }\end{array}$ & & \\
\hline 16 & $\begin{array}{l}\text { Doğancı } \\
\text { Ahmet Paşa }\end{array}$ & 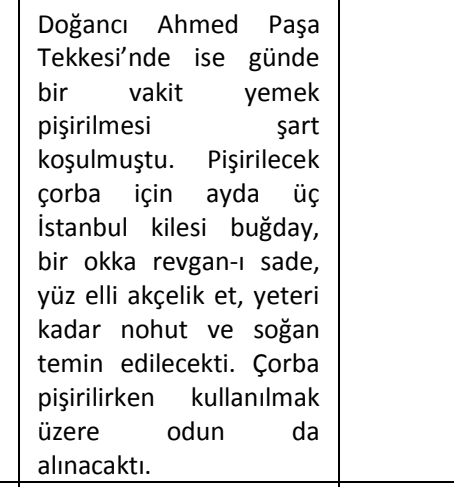 & & \\
\hline 17 & $\begin{array}{l}\text { Yahya } \\
\text { Kethüda }\end{array}$ & Günlük üç akçe & & \\
\hline \multicolumn{5}{|c|}{ Beslenme îhtiyacını Mensup Olduğu Külliyenin İmaretinden Karşılayan Tekkeler } \\
\hline & Tekke adı & Yemek tahsisatı & $\begin{array}{l}\text { Vakfedilen } \\
\text { matbah eşyası }\end{array}$ & $\begin{array}{l}\text { Personel } \\
\text { ücreti }\end{array}$ \\
\hline 1 & Atik Valide & $\begin{array}{l}\text { Külliye imaretinden dervişler için } \\
\text { günde iki defa on sekiz tam yemek } \\
\text { verilmesi şart koşulmuştu }\end{array}$ & & \\
\hline 2 & $\begin{array}{l}\text { Atik Ali } \\
\text { Paşa }\end{array}$ & $\begin{array}{l}\text { Külliye imaretinden dervişlere günde } \\
\text { iki öğün yemek verildiği bilinmekteyse } \\
\text { de miktarı bilinmemektedir }\end{array}$ & & \\
\hline 3 & $\begin{array}{l}\text { Koca } \\
\text { Mustafa } \\
\text { Paşa }\end{array}$ & $\begin{array}{l}\text { Vakfiyede külliye imaretine yemek için } \\
\text { tahsis edilmiş para toplu olarak } \\
\text { verilmiş, ama bunun ne kadarının } \\
\text { tekke için ayrıldığı tasrih edilmemiştir. } \\
\text { Sadece mübarek gün ve gecelerde } \\
\text { tekke için ayrılan tahsisata dair bilgi } \\
\text { vardır. Buna göre tekkede aşure ayının } \\
\text { ilk günü on beş okka aşure dağıtılması; } \\
\text { cuma ve ramazan gecelerinde ise on } \\
\text { beş okka yağın yemekler için } \\
\text { kullanııması şart koşulmuştu }\end{array}$ & & \\
\hline
\end{tabular}




\section{Ek-III) Kadırga Sokullu Mehmet Paşa Tekkesi}
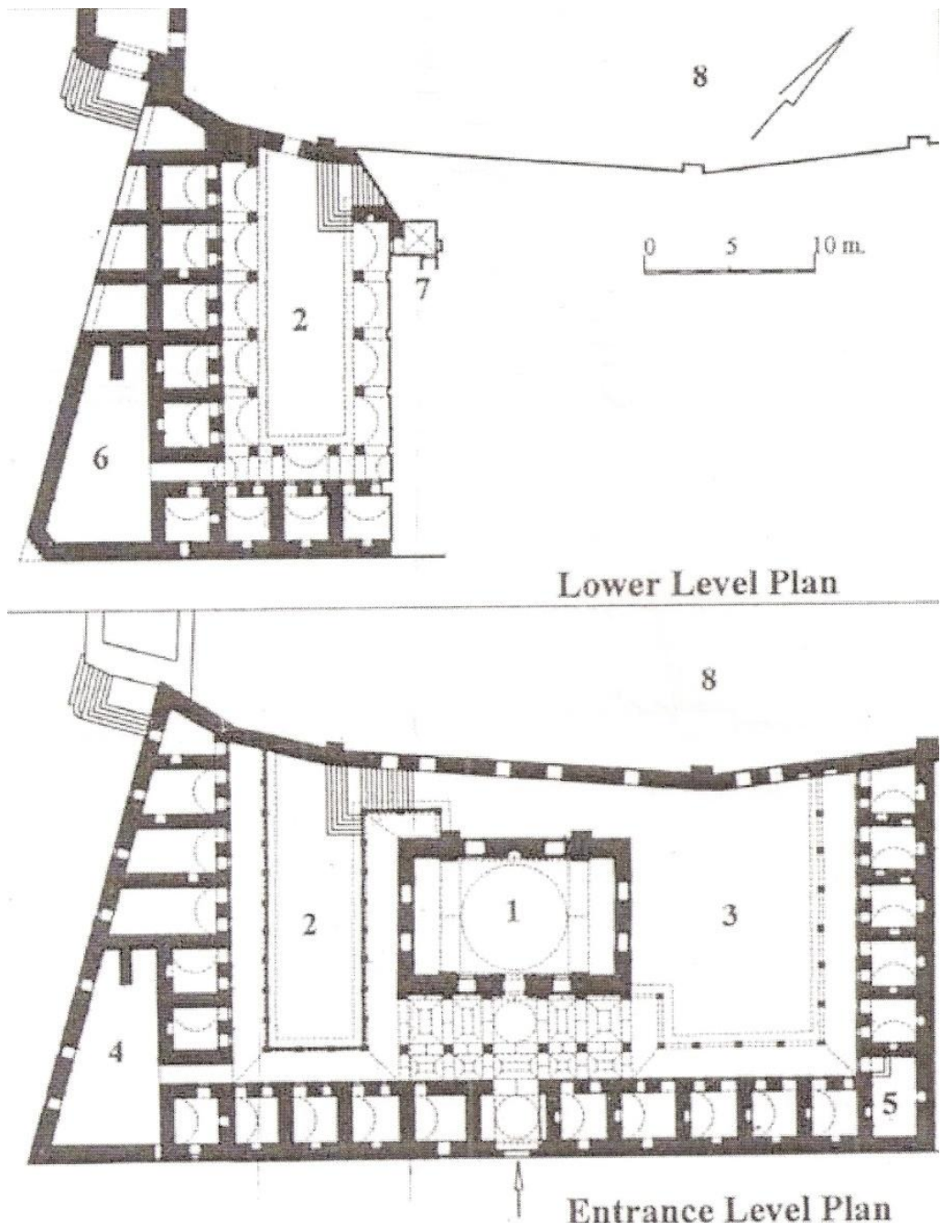

1-) Tevhidhane, 2-) Alt koridor, 3-) Üst koridor, 4-) Şeyh odaları, 5-) Halvethane (?), 6-) Mutfak ve yemekhane, 7-) Tuvaletler, 8-) Hazire (Yürekli, agm, s. 162). 
Ek-IV) Atik Valide Külliyesi

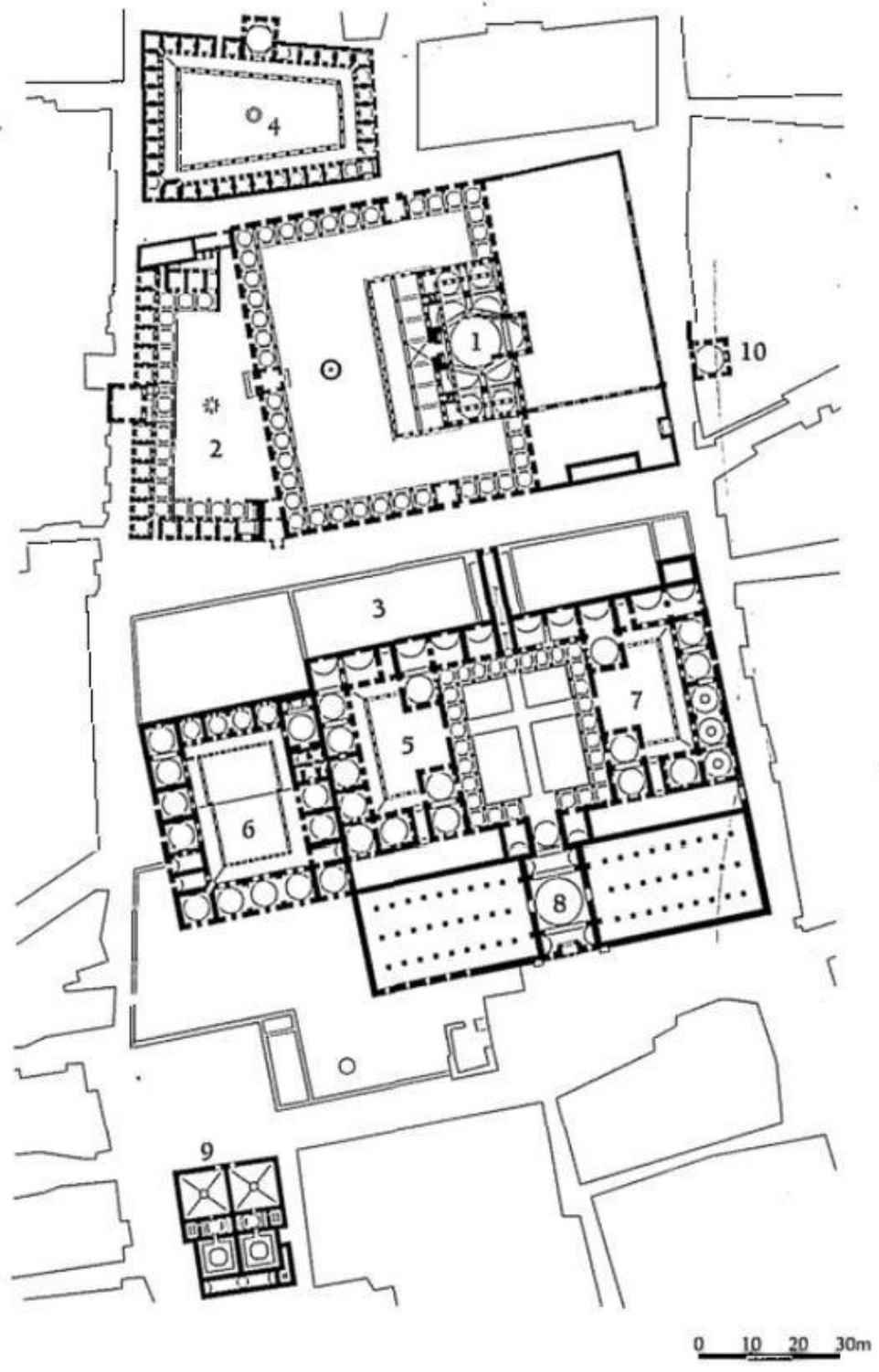

1-) Cami, 2-) Medrese, 3-) Darülhadis, 4-) Tekke, 5-) Tabhane, 6-) Darüşşifa, 7-) Imaret, 8-) Kervansaray, 9-) Hamam, 10-) Sıbyan Mektebi (Ali Saim Ülgen) 